\begin{tabular}{|c|c|}
\hline Title & $\begin{array}{l}\text { Nitrous oxide emission derived from soil organic matter decomposition from tropical agricultural peat soil in central } \\
\text { Kalimantan, Indonesia }\end{array}$ \\
\hline Author(s) & $\begin{array}{l}\text { Toma, Yo; Takakai, Fumiaki; Darung, Untung; Kuramochi, Kanta; Limin, Suwido H.; Dohong, Sal ampak; Hatano, } \\
\text { Ryusuke }\end{array}$ \\
\hline Citation & $\begin{array}{l}\text { Soil Science and Plant Nutrition, } 57(3), 436-451 \\
\text { https:/doi.org/10.1080/00380768.2011.587203 }\end{array}$ \\
\hline Issue Date & $2011-07-26$ \\
\hline Doc URL & http:/hdl .handle.net/2115/49648 \\
\hline Rights & $\begin{array}{l}\text { This is an electronic version of an article published in Soil Science and Plant Nutrition, } 57(3), 2011 \text {, pp. } 436-451 \text {. Soil } \\
\text { Science and Plant Nutrition is available online at: http:/www.informaworld.com/openurl ?genre=article\&issn=0038 } \\
\text { 0768\& volume }=57 \& \text { issue }=3 \& \text { spage }=436\end{array}$ \\
\hline Type & article (author version) \\
\hline File Information & SSPN57-3_436-451.pdf \\
\hline
\end{tabular}

Instructions for use 


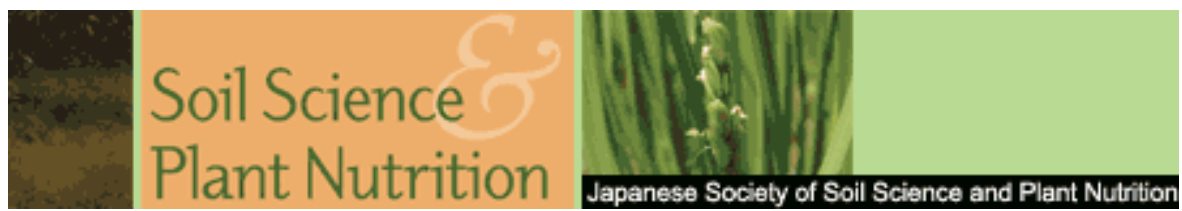

\section{Nitrous oxide emission derived from soil organic matter decomposition from tropical agricultural peat soil in Central Kalimantan, Indonesia}

\begin{tabular}{|r|l|}
\hline Journal: & Soil Science and Plant Nutrition \\
\hline Manuscript ID: & SSPN-11-060-F.R2 \\
\hline Manuscript Type: & Full-length paper \\
\hline Complete List of Authors: & $\begin{array}{l}\text { Toma, Yo; Field science center for Northern Biosphere, Hokkaido } \\
\text { University } \\
\text { Takakai, Fumiaki; Akita Prefectural University, Laboratory of Soil } \\
\text { Science, Faculty of Bioresource Sciences } \\
\text { Darang, Untung; Universiy of Palangka Raya, Fuculty of agriculture } \\
\text { kuramochi, kanta; Hokkaido University, Graduate School of } \\
\text { Agriculture } \\
\text { Limin, Suwido; University of Palangka Raya, Faculty of Agriculture } \\
\text { Dohong, Salampak; University of Palangka Raya, Faculty of } \\
\text { Agriculture } \\
\text { HATANO, Ryusuke; Hokkaido University, Graduate School of } \\
\text { Agriculture }\end{array}$ \\
\hline Keywords: & \begin{tabular}{l} 
global environment < Environment, upland soils < Soil Fertility \\
\hline \hline
\end{tabular} \\
\hline
\end{tabular}

\section{SCHOLARONE ${ }^{\text {M }}$ \\ Manuscripts}


1 Nitrous oxide emission derived from soil organic matter decomposition from tropical

2 agricultural peat soil in Central Kalimantan, Indonesia

3

4 Running title: $\mathrm{N}_{2} \mathrm{O}$ emission from agricultural peat soil

6 Yo Toma ${ }^{1, *}$, Fumiaki Takakai ${ }^{2}$, Untung Darung ${ }^{3}$, Kanta Kuramochi ${ }^{4}$, Suwido H. Limin ${ }^{3}$,

$7 \quad$ Salampak Dohong $^{3}$, Ryusuke Hatano ${ }^{4}$

8

$9{ }^{1}$ Field Science Center for Northern Biosphere, Hokkaido University, Kita 11 Nishi 10, Kita-ku, 10 Sapporo 060-8589, Japan

11 Yo Toma's e-mail: toma@fsc.hokudai.ac.jp

$13{ }^{2}$ Faculty of Bioresource Sciences, Akita Prefectural University, 241-438 Aza Kaidobata-Nishi,

14 Shimoshinjo, Nakano, Akita 010-0195, Japan

15 Fumiaki Takakai’s e-mail: takakai@akita-pu.ac.jp 16

$17{ }^{3}$ Faculty of Agriculture, University of Palangka Raya, Palangka Raya 73112, Central

18 Kalimantan, Indonesia

19 Untung Darung's e-mail: untdar@yahoo.com

20 Suwido H. Limin's e-mail: cimtrop_suwido@ yahoo.com

21 Salampak Dohong's e-mail: salamdong@hotmail.com

22

$23{ }^{4}$ Research Faculty of Agriculture, Hokkaido University, Kita 9 Nishi 9, Kita-ku, Sapporo 060248589 , Japan

25 Kanta Kuramochi’s e-mail: kanta@chem.agr.hokudai.ac.jp 
26 Ryusuke Hatano’s e-mail: hatano@chem.agr.hokudai.ac.jp

27

$28 *$ * Corresponding author: postal address: Field Science Center for Northern Biosphere,

29 Hokkaido University, Kita 11 Nishi 10, Kita-ku, Sapporo 060-8589, Japan; tel: +81-11-706-

30 2854; fax: +81-11-706-3644; e-mail: toma@ fsc.hokudai.ac.jp

31

32 Keywords: Tropical peatland; Organic matter decomposition; Nitrous oxide; Carbon dioxide;

33 Denitrification.

34

35 Type of contribution: Full-length paper

36 Division: Environment 


\section{$37 \quad$ ABSTRACT}

38 Our previous research showed large amounts of nitrous oxide $\left(\mathrm{N}_{2} \mathrm{O}\right)$ emission $(>200 \mathrm{~kg} \mathrm{~N} \mathrm{ha}$

$39{ }^{1} \mathrm{yr}^{-1}$ ) from agricultural peat soil. In this study, we investigated the factors influencing

40 relatively large $\mathrm{N}_{2} \mathrm{O}$ fluxes and the source of nitrogen (N) substrate for $\mathrm{N}_{2} \mathrm{O}$ in a tropical

41 peatland in Central Kalimantan, Indonesia. Using a static chamber method, $\mathrm{N}_{2} \mathrm{O}$ and carbon

42 dioxide $\left(\mathrm{CO}_{2}\right)$ fluxes were measured in three conventionally cultivated croplands

43 (conventional), an unplanted and unfertilized bare treatment (bare) in each cropland, and

44 unfertilized grassland over a 3-year period. Based on the difference in $\mathrm{N}_{2} \mathrm{O}$ emission from two

45 treatments, contribution of the $\mathrm{N}$ source for $\mathrm{N}_{2} \mathrm{O}$ was calculated. Nitrous oxide concentrations

46 at five depths $(5-80 \mathrm{~cm})$ were also measured for calculating net $\mathrm{N}_{2} \mathrm{O}$ production in soil.

47 Annual $\mathrm{N}$ fertilizer application rates in the croplands ranged from 472 to $1,607 \mathrm{~kg} \mathrm{~N} \mathrm{ha}^{-1} \mathrm{yr}^{-1}$.

48 There were no significant differences in between $\mathrm{N}_{2} \mathrm{O}$ fluxes in the two treatments at each site.

49 Annual $\mathrm{N}_{2} \mathrm{O}$ emission in conventional and bare treatments varied from 10.9 to 698 and 6.55 to

$50858 \mathrm{~kg} \mathrm{~N} \mathrm{ha}^{-1} \mathrm{yr}^{-1}$, respectively. However, there was also no significant difference between

51 annual $\mathrm{N}_{2} \mathrm{O}$ emissions in the two treatments at each site. This suggests most of the emitted

$52 \mathrm{~N}_{2} \mathrm{O}$ was derived from the decomposition of peat. There were significant positive correlations

53 between $\mathrm{N}_{2} \mathrm{O}$ and $\mathrm{CO}_{2}$ fluxes in bare treatment in two croplands where $\mathrm{N}_{2} \mathrm{O}$ flux was higher

54 than at another cropland. Nitrous oxide concentration distribution in soil measured in the

55 conventional treatment showed that $\mathrm{N}_{2} \mathrm{O}$ was mainly produced in the surface soil down to 15

$56 \mathrm{~cm}$ in the soil. The logarithmic value of the ratio of $\mathrm{N}_{2} \mathrm{O}$ flux and nitrate concentration was

57 positively correlated with water filled pore space. These results suggest that large $\mathrm{N}_{2} \mathrm{O}$

58 emission in agricultural tropical peatland was caused by denitrification with high

59 decomposition of peat. In addition, $\mathrm{N}_{2} \mathrm{O}$ was mainly produced by denitrification at high range

60 of WFPS in surface soil. 


\section{INTRODUCTION}

62 Tropical peatland in Indonesia comprise nearly 12\% (27 Mha) of total global peatland

63 (Maltby and Immirzi 1993). However, large areas of the tropical peatlands, have been

64 damaged by forest fires or agricultural deforestation in Indonesia (Muhanmad and Rieley

65 2002; Page et al. 2002). In 1995, more than 1 Mha of tropical peat land in Central Kalimantan

66 in Indonesia was reclaimed for agricultural development by the "Mega Rice Project"

67 (Muhanmad and Rieley 2002). Moreover, $28 \%$ of peat swamp forest was burned in Central

68 Kalimantan in 1997 (Page et al. 2002). In addition to the large-scale degradation and

69 relatively large amount of carbon dioxide $\left(\mathrm{CO}_{2}\right)$ release by drainage and associated peat fires

70 (Hooijer et al. 2006; Page et al. 2002), cultivation in tropical peat soil has possibly led to

71 increased nitrous oxide $\left(\mathrm{N}_{2} \mathrm{O}\right)$ emission (Takakai et al. 2006; Terry et al. 1981). Increasing

72 atmospheric $\mathrm{N}_{2} \mathrm{O}$ concentration appears to have been caused by human activities (IPCC 2007).

73 Nitrous oxide is not only a greenhouse gas, but also one of the major ozone-depleting

74 substances in the atmosphere (Ravishankara et al. 2009). Soil is an important source of

75 atmospheric $\mathrm{N}_{2} \mathrm{O}$ (Mosier et al. 1998). Nitrous oxide emission from agricultural land has been

76 estimated to be $21.6 \%\left(3.6 \mathrm{Tg} \mathrm{N} \mathrm{yr}^{-1}\right)$ of total global emission of $\mathrm{N}_{2} \mathrm{O}\left(16.2 \mathrm{Tg} \mathrm{N} \mathrm{yr}^{-1}\right)$ (IPCC

77 1995). There are, however, several studies documenting $\mathrm{N}_{2} \mathrm{O}$ emissions not only from natural

78 tropical peatlands, but also those under cultivation (Hadi et al. 2005; Inubushi et al. 2003;

79 Melling et al. 2007; Takakai et al. 2006; Terry et al. 1981).

80 An issue of the $\mathrm{N}_{2} \mathrm{O}$ emission study in agricultural tropical peatland is that factors

81 influencing $\mathrm{N}_{2} \mathrm{O}$ emission and the sources of $\mathrm{N}$ for $\mathrm{N}_{2} \mathrm{O}$ emission have still been unclear.

82 Several studies in agricultural boreal peatland (e.g. in Finland and Norway) have reported that

$83 \mathrm{~N}_{2} \mathrm{O}$ emissions from drained peatland ranged from 0.1 to $37 \mathrm{~kg} \mathrm{~N} \mathrm{ha}^{-1} \mathrm{yr}^{-1}$ (Klemedtsson et al.

84 2005; Maljanen et al. 2003; Regina et al. 2004). These values were notably larger than the

$85 \mathrm{~N}_{2} \mathrm{O}$ emission from agricultural fields on mineral soils $\left(0.9-6.4 \mathrm{~kg} \mathrm{~N} \mathrm{ha}^{-1} \mathrm{yr}^{-1}\right.$, Bouwman et al. 
2002). On the other hand, $\mathrm{N}_{2} \mathrm{O}$ emission from agricultural tropical peatland is reported to be much more variable. The values have been estimated to range from -1.1 to $259 \mathrm{~kg} \mathrm{~N} \mathrm{ha}^{-1} \mathrm{yr}^{-1}$ (Hadi et al. 2005; Inubushi et al. 2003; Melling et al. 2007; Takakai et al. 2006; Terry et al. 1981). It is also reported $\mathrm{N}_{2} \mathrm{O}$ emission increased following change in land use from natural peat swamp forest to drained or burned peatland, and to agricultural peatland (Melling et al. 2007; Takakai et al. 2006).

In addition to the emission factor $\left(\mathrm{EF}_{\mathrm{F}}\right)$ induced by applied $\mathrm{N}$ fertilizer, $\mathrm{N}_{2} \mathrm{O}$ emission induced by cultivation of peatland is important for the calculation of annual $\mathrm{N}_{2} \mathrm{O}$ emission from agricultural fields on peatland. In the subarctic zone, Regina et al. (2004) reported $\mathrm{N}_{2} \mathrm{O}$ emission from grass, barley and potato vegetation plots (2.6-24.1 $\left.\mathrm{kg} \mathrm{N} \mathrm{ha}^{-1} \mathrm{yr}^{-1}\right)$ were smaller relative to fallow plots $\left(3.8-37 \mathrm{~kg} \mathrm{~N} \mathrm{ha}^{-1} \mathrm{yr}^{-1}\right)$ on boreal peatland in Finland. This means $\mathrm{N}$ source for $\mathrm{N}_{2} \mathrm{O}$ emission from soil organic matter ( $\mathrm{SOM}$ ) was larger than $\mathrm{N}_{2} \mathrm{O}$ emission induced by the application of $\mathrm{N}$ fertilizer. Moreover, Regina et al. (2004) reported that average $\mathrm{N}_{2} \mathrm{O}$ emission induced by $\mathrm{SOM}$ was $10.4 \mathrm{~kg} \mathrm{~N}$ ha $^{-1} \mathrm{yr}^{-1}$. Although, index of $\mathrm{N}_{2} \mathrm{O}$ emission induced by cultivation in tropical peatland was proposed by IPCC (2006) to be 16 $\mathrm{kg} \mathrm{N} \mathrm{ha}^{-1} \mathrm{yr}^{-1}$, this value was derived from data obtained from mid-latitude peatlands.

However, some environmental conditions in peatland are notably different between boreal or temperate and tropical peatland. Mean annual air temperature is lower in boreal peatland (e.g., $5^{\circ} \mathrm{C}$ in Majnegarden, Sweden (Kasimir-Klemedtsson et al. 2009) than in tropical peatland (e.g., $26^{\circ} \mathrm{C}$ in Central Kalimantan, Indonesia (Hirano et al. 2007). Peat is mainly derived from sphagnum or herbaceous plant species in boreal or temperate peatland and from woody plant species in tropical peatland (Andriesse 1988). These vegetational differences strongly influence the production and emission of $\mathrm{N}_{2} \mathrm{O}$ from peat soil because it is mainly produced by nitrification and denitrification in soil. Combined with warm temperatures and frequent rainfall in tropical climates, application of $\mathrm{N}$ fertilizer and high levels of organic matter in soil 
111 may enhance $\mathrm{N}_{2} \mathrm{O}$ production through nitrification and denitrification (Bouwman 1996;

112 Bremner 1997; Tiedje 1994). Warm climates in tropical regions also allow multiple crop

113 cultivations within a single year, which may cause rapid decomposition of peat soil due to

114 plowing. Therefore, it is difficult to simply apply what is known regarding $\mathrm{N}_{2} \mathrm{O}$ dynamics in

115 boreal or temperate peatland to tropical peatland.

116 Takakai et al. (2006) reported large amount of annual $\mathrm{N}_{2} \mathrm{O}$ emission (at most $259 \mathrm{~kg} \mathrm{~N} \mathrm{ha}^{-1}$

$117 \mathrm{yr}^{-1}$ ) and high $\mathrm{EF}_{\mathrm{F}}$ value in the cultivated tropical peatland of this study located in Central

118 Kalimantan, Indonesia. For the rough calculation of $\mathrm{EF}_{\mathrm{F}}, \mathrm{N}_{2} \mathrm{O}$ emission in unfertilized and

119 unplowed grassland was assumed to be that derived from SOM decomposition of peat. As

120 such, their reported $\mathrm{EF}_{\mathrm{F}}$ would be influenced by the $\mathrm{N}_{2} \mathrm{O}$ emission induced by the cultivation

121 of peatland, and possibly be over- or underestimated. Understanding the mechanisms of such

122 high $\mathrm{N}_{2} \mathrm{O}$ production and emission in agricultural tropical peatland will be essential for

123 quantifying $\mathrm{N}_{2} \mathrm{O}$ emission and developing the mitigation method for $\mathrm{N}_{2} \mathrm{O}$ emission. The

124 objectives of our study were to clarify the factors that influence $\mathrm{N}_{2} \mathrm{O}$ emission, identifying the

125 source of $\mathrm{N}$ substrate for $\mathrm{N}_{2} \mathrm{O}$, and to quantify annual $\mathrm{N}_{2} \mathrm{O}$ emission in tropical agricultural

126 peatland in Central Kalimantan, Indonesia. 


\section{MATERIALS AND METHODS}

\section{Site description}

129 This study was conducted in Kalampangan Village ( $\left.2^{\circ} 17^{\prime} \mathrm{S}, 114^{\circ} 1^{\prime} \mathrm{E}\right)$ near Palangka Raya

130 City $\left(2^{\circ} \mathrm{S}, 114^{\circ} \mathrm{E}\right)$ in Central Kalimantan, Indonesia, from March 2004 to March 2007. In this 131 region, the dry season normally begins in June and ends in October (Takakai et al. 2006).

132 Four adjacent study plots, which were designated as cropland A, B, and C (CL-A, CL-B, CL133 C) and grassland (GL), were located in center of the village and set up in March 2002 134 (Takakai et al. 2006). In those plots, cultivation practice was managed by owner farmer. 135 Cultivation has begun in 1980 on CL-A, CL-B, and GL, and in 1996 on CL-C. After plowing, 136 croplands were cultivated with cassava (Manihot esculenta Crants.), maize (Zea mays L.) or 137 vegetables (e.g., egg plants (Solanum melongena), etc.).The vegetation in GL was turf grass 138 which has been harvested or grazed. Crop cultivation and fertilization practice were managed 139 by owner farmers. Average $\mathrm{N}$ fertilizer applied in CL-A, CL-B, and CL-C sites were 1,607, 140472 and $1,113 \mathrm{~kg} \mathrm{~N} \mathrm{ha}^{-1} \mathrm{yr}^{-1}$, respectively (Table 1). The soil classification according to 141 USDA Soil Taxonomy at all the study sites was Histosols (Typic Tropofibrists, Takakai et al. 142 2006). Thickness of peat was $2.6-2.8 \mathrm{~m}$. Bulk density and porosity of surface soil $(0-10 \mathrm{~cm})$ 143 were approximately $0.4 \mathrm{~g} \mathrm{~cm}^{-3}$ and $73-77 \%$, respectively. Total $\mathrm{C}$ and $\mathrm{N}$ concentration in 144 surface soil $(0-10 \mathrm{~cm})$ varied from 530 to 632 and 13 to $14.3 \mathrm{~g} \mathrm{~kg}^{-1}$, respectively. Detail 145 information about soil chemical and physical characteristics and the method of soil analysis 146 was described in Takakai et al. (2006).

\section{Treatments}

149 Fields in CL-A, CL-B and CL-C were defined as conventional cultivation (conventional) 150 treatments. Unplanted and unfertilized bare (bare) treatments, which were $0.5 \mathrm{~m}^{2}(1 \mathrm{~m} \times 0.5 \mathrm{~m})$ 151 in area, were established in CL-A, CL-B, and CL-C in April 2004 for estimating $\mathrm{N}_{2} \mathrm{O}$ 
152 emission derived from SOM decomposition and were maintained as such for the duration of

153 the study period. Thin woody plates were installed around the bare treatments down to $20 \mathrm{~cm}$ 154 deep in the soil to prevent root intrusion and soil contamination. In the conventional treatment 15

in CL-A, CL-B, and CL-C, chemical and organic fertilizers were applied by farmer every cultivation at the point seeds were sown, which was based on common agricultural practices

157 in the area. Organic fertilizer was produced from cattle manure kept by farmer and grass.

158 Fertilizer was not applied during the duration of the study period in GL.

159

\section{Nitrous oxide and carbon dioxide flux measurements and soil nitrous oxide gas}

Nitrous oxide and $\mathrm{CO}_{2}$ fluxes were measured with a closed-chamber method with three replications at each site and treatment (Takakai et al. 2006). Gas fluxes were measured once a month from April 2004 to February 2006 and twice a month after March 2006 to March 2007.

We followed $\mathrm{N}_{2} \mathrm{O}$ and $\mathrm{CO}_{2}$ gas sampling method provided by Takakai et al. (2006), Nakano et al. (2004) and Toma and Hatano (2007). Air temperature at a height of $1 \mathrm{~m}$ was measured with a thermometer at the same day of $\mathrm{N}_{2} \mathrm{O}$ and $\mathrm{CO}_{2}$ gas fluxes measurement. et al. (2003) to sample soil gas sampling and calculate $\mathrm{N}_{2} \mathrm{O}$ production and consumption in 170 soil.

Nitrous oxide and carbon dioxide concentration analysis, calculation of nitrous oxide and carbon dioxide fluxes, annual emission of nitrous oxide, and nitrogen fertilizer induced emission factor of nitrous oxide $\left(\mathbf{E F}_{\mathrm{F}}\right)$ the analysis of $\mathrm{N}_{2} \mathrm{O}$ concentration were analyzed within 12 hour and a month, respectively, 
177 after collecting these samples. Nitrous oxide and $\mathrm{CO}_{2}$ concentrations were analyzed with a 178 gas chromatograph (GC-14B, Shimadzu, Kyoto, Japan) equipped with an electron-capture 179 detector and $\mathrm{CO}_{2}$ analyzer (ZFP-9, Fuji Electric Systems, Tokyo, Japan), respectively. Gas 180 fluxes were calculated following the method provided by Toma and Hatano (2007).

181 The annual $\mathrm{N}_{2} \mathrm{O}$ emissions were calculated by linear integration of flux measurements during 182 the measurement period (Toma and Hatano 2007; Toma et al. 2010).

183 Emission factor induced by nitrogen fertilizer (chemical and organic nitrogen) was 184 calculated by the following equations for data collected in CL-A, CL-B, and CL-C: $\mathrm{EF}_{\mathrm{F}}(\%)=\left(\mathrm{N}_{2} \mathrm{O}_{\mathrm{C}}-\mathrm{N}_{2} \mathrm{O}_{\mathrm{B}}\right) /($ applied chemical and organic $\mathrm{N}) \times 100$

186 where $\mathrm{N}_{2} \mathrm{O}_{\mathrm{C}}$ is the annual $\mathrm{N}_{2} \mathrm{O}$ emission in the conventional treatment $\left(\mathrm{kg} \mathrm{N} \mathrm{ha}^{-1} \mathrm{yr}^{-1}\right)$ and $187 \mathrm{~N}_{2} \mathrm{O}_{\mathrm{B}}$ is the annual $\mathrm{N}_{2} \mathrm{O}$ emission in bare treatment $\left(\mathrm{kg} \mathrm{N} \mathrm{ha}^{-1} \mathrm{yr}^{-1}\right) . \mathrm{EF}_{\mathrm{F}}$ was calculated when 188 there was a significant difference in $\mathrm{N}_{2} \mathrm{O}$ emission between conventional and bare treatments. 189 Otherwise, $\mathrm{EF}_{\mathrm{F}}$ was defined as $0 \%$.

\section{Calculation of net nitrous oxide production rate in soil}

192 Net $\mathrm{N}_{2} \mathrm{O}$ production rate is the difference between gross $\mathrm{N}_{2} \mathrm{O}$ production rate and gross $\mathrm{N}_{2} \mathrm{O}$ 193 consumption rate. Net $\mathrm{N}_{2} \mathrm{O}$ production rate was calculated using the following equation based 194 on Fick’s Law (gradient method; Granli and Bøckman 1994):

$$
\text { Net } \mathrm{N}_{2} \mathrm{O} \text { production rate }=\mathrm{F}(\mathrm{I}+1)-\mathrm{F}(\mathrm{I})
$$
where $\mathrm{F}$ is the gas flux $\left(\mathrm{mg} \mathrm{m}^{-2} \mathrm{~s}^{-1}\right)$ and $\mathrm{I}$ in the parenthesis is the depth increment number. We 197 followed the method of Kusa et al. (2008) for the calculation of net $\mathrm{N}_{2} \mathrm{O}$ production rate from 198 the soil layer of $0-2.5,2.5-7.5,7.5-15,15-30$, and 30-60-cm depths. 
202 Soil temperature at a depth of $4 \mathrm{~cm}$, volumetric soil water content from 0 to 6-cm depth, and

203 water table depth were measured during the gas flux measurements. Soil temperature was

204 measured in both conventional and bare treatments using a thermistor thermometer.

205 Amplitude domain reflectometry (ADR, ML2 Theta Probe Delta-T Devices, Cambridge, UK)

206 was used to measure the volumetric soil water content in both conventional and bare

207 treatments. The resulting volumetric soil water content was converted into a value for water-

208 filled pore space (WFPS), which represents the ratio of the volumetric water content to the

209 total porosity of the soil, by assuming that the porosity measured by Takakai et al. (2006) in

210 February 2005 was consistent throughout the measurement period. There were three

211 replications per chamber for the soil temperature and volumetric soil water content

212 measurements. To measure the water table depth, perforated PVC pipes (1.57 inch in

213 diameter) were inserted into the peat soil at each site. Air temperature and precipitation were

214 measured every half hour using a 50-m micrometeorological tower established inside the

215 forest that was about $3 \mathrm{~km}$ from the study site (Hirano et al. 2005; 2007). Disturbed soil

216 samples in conventional treatments were collected for soil $\mathrm{NH}_{4}{ }^{+}$and $\mathrm{NO}_{3}{ }^{-}$concentrations

217 from 0-3-cm and 3-10-cm-depth between March 2004 and February 2006, and from 0 to 10-

218 cm depth between March 2006 and March 2007 at the same day of gas flux measurement. In

219 bare treatment at each site, soil samples were collected only two times in September 2006 (in

220 dry season) and February 2007 (in rainy season). Collected soil samples were frozen until soil

$221 \mathrm{NH}_{4}{ }^{+}$and $\mathrm{NO}_{3}{ }^{-}$concentrations of those samples were analyzed. Soil $\mathrm{pH}\left(\mathrm{H}_{2} \mathrm{O}\right.$ basis $)$ was

222 measured with a glass electrode $\mathrm{pH}$ meter ( $\mathrm{pH}$ meter F-22, Horiba, Kyoto, Japan) in a 1:20

223 soil:deionized water mixture. Concentration of $\mathrm{NO}_{3}{ }^{-}$in this suspension was also measured

224 using ion chromatography (Dionex QIC Analyzer, Dionex Japan, Osaka, Japan). Ammonium

225 in the soil was extracted with $2 \mathrm{~mol} \mathrm{~L}^{-1}$ potassium chloride solution (1:20 dried soil:water).

226 Ammonium concentration was determined using colorimetry based on the indophenol-blue 
227 method with a UV-VIS spectrophotometer (UV mini 1240, Shimadzu, Kyoto, Japan).

228 Ammonium and $\mathrm{NO}_{3}{ }^{-}$concentrations in soil samples, which were collected at the 0-10-cm

229 depth from March 2004 to February 2006, were calculated by the weighted average of each

230 concentration in soil samples from the $0-3-\mathrm{cm}$ and $3-10-\mathrm{cm}$ depth.

232 Statistical analysis

233 Comparisons of soil temperature and WFPS between conventional and bare treatments in CL-

234 A, CL-B, and CL-C were analyzed with the Mann-Whitney's $U$-test (non-parametric).

235 Comparisons of $\mathrm{N}_{2} \mathrm{O}$ fluxes or annual $\mathrm{N}_{2} \mathrm{O}$ emissions between conventional and bare

236 treatments were performed using Student's $t$-test (parametric) based on studies that report

$237 \mathrm{~N}_{2} \mathrm{O}$ flux shows a log-normal distribution (Van-Cleemput et al. 1994; Velthof and Oenema

238 1995). Therefore, values of $\mathrm{N}_{2} \mathrm{O}$ flux or annual $\mathrm{N}_{2} \mathrm{O}$ emission were transformed logarithm

239 values when student's $t$-test was carried out. The least significant difference test was used to

240 determine significant differences $(P<0.05)$. One-sided $95 \%$ confidence interval of $\mathrm{N}_{2} \mathrm{O}$

241 emission data was calculated by using the following equation:

242 one-sided $95 \%$ confidence interval $=\mathrm{t}($ d.f., 0.05$) \mathrm{x}$ standard error

243 where d.f. is the degree of freedom, and $t($ d.f., 0.05$)$ is the $t$ value at $5 \%$ significant level with

244 two-sided alternative. Spearman's rank correlation coefficient was used for the analysis of

245 relationship between $\mathrm{N}_{2} \mathrm{O}$ flux and water table depth, soil temperature, WFPS, $\mathrm{NH}_{4}{ }^{+}$and $\mathrm{NO}_{3}{ }^{-}$

246 concentrations or $\mathrm{CO}_{2}$ flux in conventional treatments during the study period in CL-A, CL-B, 247 CL-C, and GL. 


\section{RESULTS}

249 Nitrous oxide fluxes in conventional and bare treatments in all plots increased from

250 November to April (Figs. 1-4). Ranges of $\mathrm{N}_{2} \mathrm{O}$ fluxes during the study period in conventional 251 treatments in CL-A, CL-B, and CL-C were 0-38, 0-1.46, and 0-9.27 $\mathrm{mg} \mathrm{N} \mathrm{m}^{-2} \mathrm{~h}^{-1}$, 252 respectively. On the other hand, $\mathrm{N}_{2} \mathrm{O}$ fluxes in bare treatment in CL-A, CL-B, and CL-C were $2530-43,0-0.98$, and $0-12 \mathrm{mg} \mathrm{N} \mathrm{m}^{-2} \mathrm{~h}^{-1}$, respectively. Average $\mathrm{N}_{2} \mathrm{O}$ fluxes in conventional 254 treatment from April to June, July to September, October to December and January to March 255 significantly increased with increasing precipitation in each plot except for CL-C (CL-A y = $2560.023 \mathrm{x}-0.584, R=0.55, P<0.05 ; \mathrm{CL}-\mathrm{B} \mathrm{y}=0.0005 \mathrm{x}-0.078, R=0.64, P<0.05 ; \mathrm{CL}-\mathrm{C} \mathrm{y}=$ $2570.0019 \mathrm{x}-0.037, R=0.30, P=0.18 ; \mathrm{GL} \mathrm{y}=0.0011 \mathrm{x}-0.134, R=0.57, P<0.05)$. There were 258 no significant differences in $\mathrm{N}_{2} \mathrm{O}$ fluxes between conventional and bare treatments in CL-A, 259 CL-B, and CL-C (Table 2). Nitrous oxide production rates were relatively high at 2.5-15-cm 260 depth of soil compared to that below 15-cm depth in all plots (Table 3).

261 Although the seasonal trend of water table depth was not clear, average water table depths 262 in conventional treatments in CL-A, CL-B, CL-C, and GL were 67.2, 77.1, 67.8, and $87.7 \mathrm{~cm}$, 263 respectively (Figs. 1b-4b). In all plots, soil temperature was stable around $30{ }^{\circ} \mathrm{C}$ (Figs. 1c-4c).

264 There were no significant differences in soil temperature between conventional and bare 265 treatments for the duration of the study (Table 2). Water-filled pore space in each plot tended 266 to be high (around 80\%) from November to April in all years (Figs. 1-4). There were no 267 significant differences in WFPS between conventional and bare treatments in CL-A, CL-B, 268 and CL-C (Table 2). Clear seasonal trends of soil $\mathrm{NH}_{4}{ }^{+}$and $\mathrm{NO}_{3}{ }^{-}$concentrations in the plots 269 were not observed (Figs. 1e-4e). The average $\mathrm{NH}_{4}{ }^{+}$concentrations in conventional treatments 270 in CL-A, CL-B, CL-C, and GL were 59.4, 35.2, 18.5, and $65.8 \mathrm{mg} \mathrm{N} \mathrm{kg}^{-1}$, respectively. 271 Average $\mathrm{NO}_{3}{ }^{-}$concentrations in conventional treatments in CL-A, CL-B, CL-C, and GL were $272249,40.8,111$, and $63.7 \mathrm{mg} \mathrm{N} \mathrm{kg}^{-1}$ respectively. Nitrate concentrations in CL-A and CL-C 
273 tended to be higher than in CL-B and GL. Average $\mathrm{NH}_{4}{ }^{+}$concentrations in bare treatments in 274 CL-A, CL-B and CL-C were $10.8,10.8$, and $13.6 \mathrm{mg} \mathrm{N} \mathrm{kg}^{-1}$, respectively. Average $\mathrm{NO}_{3}{ }^{-}$ 275 concentrations in bare treatments in CL-A, CL-B, and CL-C were 99.9, 2.6, and $12.5 \mathrm{mg} \mathrm{N}$ $276 \mathrm{~kg}^{-1}$, respectively. Values of $\mathrm{NH}_{4}{ }^{+}$and $\mathrm{NO}_{3}{ }^{-}$concentrations in soil in bare treatment were 277 lower than the values in conventional treatments in CL-A, CL-B, and CL-C (Figs. 1e-3e). 278 Water table depth and WFPS were almost equivalent between CL-A and CL-C (Figs. 1d, 4d). 279 There were no consistent relationships at any of the plots between $\mathrm{N}_{2} \mathrm{O}$ flux and water table 280 depth, soil temperature, $\mathrm{NH}_{4}{ }^{+}$or $\mathrm{NO}_{3}{ }^{-}$contents (Table 4). However, $\mathrm{N}_{2} \mathrm{O}$ flux in CL-A, CL-B, 281 and GL significantly increased with increasing WFPS. In addition, $\mathrm{N}_{2} \mathrm{O}$ fluxes in CL-A and 282 CL-C, in which $\mathrm{N}_{2} \mathrm{O}$ fluxes were relatively high compared with CL-B and GL, were 283 significantly and positively correlated with $\mathrm{CO}_{2}$ fluxes (Table 4). Although not significant, $284 \mathrm{~N}_{2} \mathrm{O}$ increased with increasing $\mathrm{CO}_{2}$ flux in bare treatment in CL-A and CL-B (CL-A y = 17.7x $285-5.65, R=0.36, P=0.06 ;$ CL-B y $=0.46 \mathrm{x}-0.04, R=0.53, P<0.01 ; \mathrm{CL}-\mathrm{C} \mathrm{y}=0.35 \mathrm{x}-2.40$, $286 R=0.02, P=0.93)$. In all plots, the ratio of $\mathrm{N}_{2} \mathrm{O}$ flux and soil $\mathrm{NO}_{3}{ }^{-}$concentration at $\log$ scale $287\left\{\mathrm{Ln}\left(\mathrm{N}_{2} \mathrm{O} / \mathrm{NO}_{3}{ }^{-}\right)\right\}$were significantly correlated with WFPS (Fig. 5). However, the slope of $288 \mathrm{Ln}\left(\mathrm{N}_{2} \mathrm{O} / \mathrm{NO}_{3}{ }^{-}\right)$against WFPS was higher in CL-A (0.13) compared with other plots (0.05 to 289 0.08). Carbon dioxide flux in bare treatment tended to increase in the rainy season in CL-A, 290 CL-B, and CL-C (Figs. 1f-3f).

291 Average annual $\mathrm{N}_{2} \mathrm{O}$ emissions during the study period in conventional treatment in CL-A, 292 CL-B, CL-C, and GL were 580, 25.1, 92.5 and $43.1 \mathrm{~kg} \mathrm{~N} \mathrm{ha}^{-1} \mathrm{yr}^{-1}$, respectively (Table 5). 293 Significant linear correlations between annual $\mathrm{N}_{2} \mathrm{O}$ emission in conventional treatment in all 294 plots and annual mean air temperature or annual precipitation were not observed (mean air 295 temperature, $P=0.29$; annual precipitation, $P=0.47$ ). In CL-A and CL-C, in which the 296 average $\mathrm{N}$ fertilizer application rate was more than $1,000 \mathrm{~kg} \mathrm{~N} \mathrm{ha}^{-1} \mathrm{yr}^{-1}$ (Table 1), annual $\mathrm{N}_{2} \mathrm{O}$ 297 emissions in conventional treatments were larger than of those in CL-B or GL. Annual $\mathrm{N}_{2} \mathrm{O}$ 
298 emissions in conventional treatments significantly increased with $\mathrm{N}$ fertilizer application rate $299(\mathrm{y}=17.1 \exp (1.00 \mathrm{x}), R=0.70, P<0.001)$. Even though $\mathrm{N}$ fertilizer was not applied in GL, 300 annual $\mathrm{N}_{2} \mathrm{O}$ emissions were generally greater than $20 \mathrm{~kg} \mathrm{~N} \mathrm{ha}^{-1} \mathrm{yr}^{-1}$ (Table 5). Average annual $301 \mathrm{~N}_{2} \mathrm{O}$ emissions in bare treatment in CL-A, CL-B, and CL-C were 733, 6.96 and $126 \mathrm{~kg} \mathrm{~N} \mathrm{ha}^{-1}$ $302 \mathrm{yr}^{-1}$, respectively (Table 5). Significant differences in annual $\mathrm{N}_{2} \mathrm{O}$ emissions between 303 conventional and bare treatments were observed in CL-B and CL-C during April 2005 to 304 March 2006. Annual $\mathrm{N}_{2} \mathrm{O}$, however, emissions in bare treatments in CL-A, CL-B, and CL-C 305 were parallel to annual $\mathrm{N}_{2} \mathrm{O}$ emission in the conventional treatments (Table 5). $\mathrm{EF}_{\mathrm{F}}$ was 306 calculated only during April 2005 to March 2006 in CL-B and CL-C site, where annual $\mathrm{N}_{2} \mathrm{O}$ 307 emissions between the two treatments were significantly different (Table 5). $\mathrm{EF}_{\mathrm{F}}$ in CL-B and 308 CL-C were 0.81 and $3.59 \%$, respectively. At another site and period, $\mathrm{EF}_{\mathrm{F}}$ was $0 \%$ because 309 there were no significant differences in annual $\mathrm{N}_{2} \mathrm{O}$ emission between the conventional and 310 bare treatments. From these values, annual $\mathrm{N}_{2} \mathrm{O}$ emission induced by $\mathrm{N}$ fertilizer and derived 311 from $\mathrm{N}$ in SOM were estimated to 5.21 and $7.38 \mathrm{~kg} \mathrm{~N} \mathrm{ha}^{-1} \mathrm{yr}^{-1}$ in CL-B and 38.3 and $35.4 \mathrm{~kg}$ $312 \mathrm{~N} \mathrm{ha}^{-1} \mathrm{yr}^{-1}$ in CL-C, respectively, during April 2005 to March 2006. In addition, the proportion 313 of annual $\mathrm{N}_{2} \mathrm{O}$ emission derived from $\mathrm{SOM} \mathrm{N}$ to annual $\mathrm{N}_{2} \mathrm{O}$ emission was 58.6 and $48.0 \%$ in 314 CL-B and CL-C during April 2005 to March 2006, respectively. 


\section{DISCUSSION}

\section{Main process of nitrous oxide production}

317 Increases in $\mathrm{N}_{2} \mathrm{O}$ fluxes from October to May (Figs. 1g-4g) and significant correlation

318 between 3-month average $\mathrm{N}_{2} \mathrm{O}$ flux and precipitation suggest that $\mathrm{N}_{2} \mathrm{O}$ was actively produced 319 during the rainy season. Werner-Riddle et al. (2007) reported large pulse fluxes of $\mathrm{N}_{2} \mathrm{O}$ in the 320 wet season in tropical rain forests on mineral soil (e.g., Inceptisols, Oxisols) in Kenya $321\left(00^{\circ} 8^{\prime} \mathrm{N}-00^{\circ} 23^{\prime} \mathrm{N}, 34^{\circ} 46^{\prime}-34^{\circ} 58^{\prime} \mathrm{E}\right)$. Takakai et al. (2006) reported $\mathrm{N}_{2} \mathrm{O}$ flux was

322 significantly correlated with soil $\mathrm{NO}_{3}{ }^{-}$concentration at or above $60-70 \%$ WFPS in the same 323 field of this study. While clear relationships between $\mathrm{N}_{2} \mathrm{O}$ flux and water table depth, soil 324 temperature, $\mathrm{NH}_{4}{ }^{+}$or $\mathrm{NO}_{3}{ }^{-}$concentrations in all sites were not observed (Table 4), significant 325 correlations between $\mathrm{N}_{2} \mathrm{O}$ flux and WFPS in CL-A, CL-B, GL or between $\mathrm{Ln}\left(\mathrm{N}_{2} \mathrm{O} / \mathrm{NO}_{3}^{-}\right)$and 326 WFPS in all sites indicated that $\mathrm{N}_{2} \mathrm{O}$ was mainly produced by denitrification (Table 4, Fig. 5).

327 Nitrous oxide is generally produced in the processes of nitrification and denitrification 328 (Bouwman 1996; Bremner 1997; Tiedje 1994). In the denitrification process, $\mathrm{N}_{2} \mathrm{O}$ is mostly 329 reduced to $\mathrm{N}_{2}$ when WFPS is greater than $70 \%$ (Davidson et al. 2000). However, linear 330 relationships between $\mathrm{Ln}\left(\mathrm{N}_{2} \mathrm{O} / \mathrm{NO}_{3}{ }^{-}\right)$and WFPS in the conventional treatment in each site 331 suggested that $\mathrm{N}_{2} \mathrm{O}$ was not substantially reduced at high WFPS (Fig. 5). This indicates that $332 \mathrm{~N}_{2} \mathrm{O}$ reductase (nos) in $\mathrm{N}_{2} \mathrm{O}$-producing microbes in soil might be inactive even at high WFPS 333 (i.e. above 70\%). In acidic soils, higher $\mathrm{N}_{2} \mathrm{O}: \mathrm{N}_{2}$ fraction for denitrification were reported 334 (Alexander 1977). Dannenmann et al. (2008) reported $\mathrm{N}_{2}: \mathrm{N}_{2} \mathrm{O}$ ratio increased exponentially 335 with increasing $\mathrm{pH}$ in the soil Ah horizon between $\mathrm{pH}$ values of 6.2 and 7.3 in Germany. This 336 means that $\mathrm{N}_{2} \mathrm{O}: \mathrm{N}_{2}$ ratio increased with decreasing soil $\mathrm{pH}$. In our study site, $\mathrm{pH}$ in surface 337 soil was lower than 6.0. Thus, the reaction of $\mathrm{N}_{2} \mathrm{O}$ to $\mathrm{N}_{2}$ in denitrification process might be 338 small due to low soil pH. Hashidoko et al. (2008) found denitrifying bacteria 339 (Janthinobacterium spp.) in the surface soil in CL-A, and suggested the possibility of 
340 inactivity of nos of Janthinobacterium spp. Furthermore, Yanai et al. (2007) reported $\mathrm{N}_{2} \mathrm{O}$ -

341 producing fungi Fusarium oxysporum and Neocosmospora vasinfecta were isolated in CL-A.

342 Because the inactivity of nos in some fungal species were reported (Shoun et al. 2006), nos of

343 the fungi in our study sites was possibly inactive. Nitrous oxide-producing bacteria and fungi

344 without nos may potentially contribute to the high $\mathrm{N}_{2} \mathrm{O}$ flux and emission at the study site.

346 Origin of the substrate for nitrous oxide productions

347 Nitrous oxide flux was not always measured just after fertilizer $\mathrm{N}$ application and was

348 measured randomly at most two times a month. However, seasonal variation of $\mathrm{N}_{2} \mathrm{O}$ flux in

349 both conventional and bare treatments clearly showed the increase in $\mathrm{N}_{2} \mathrm{O}$ flux in rainy season.

350 In addition, differences in $\mathrm{N}_{2} \mathrm{O}$ fluxes between conventional and bare treatments were not

351 observed (Table 2). Those suggest that $\mathrm{N}_{2} \mathrm{O}$ flux induced by applied $\mathrm{N}$ fertilizer was unknown

352 or small compared with that by other form of $\mathrm{N}$ in soil such as soil organic $\mathrm{N}$, Nitrate and $\mathrm{C}$

353 are required for denitrification as an electron accepter and donor, respectively (Bouwman

354 1996; Bremner 1997). Except for in CL-B and CL-C from April 2005 to March 2006,

355 differences in annual $\mathrm{N}_{2} \mathrm{O}$ emission between conventional and bare treatments in CL-A, CL-B,

356 and CL-C also were not observed. Net $\mathrm{N}_{2} \mathrm{O}$ production rate was mostly high in the soil depth

357 of $2.5-15 \mathrm{~cm}$ (Table 3). Root barriers also were installed around bare treatments at $20-\mathrm{cm}$

358 depth. This suggests $\mathrm{N}_{2} \mathrm{O}$ produced in conventional treatment probably did not influence $\mathrm{N}_{2} \mathrm{O}$

359 flux in the bare treatments. Therefore, those indicated the source of $\mathrm{N}$ for $\mathrm{N}_{2} \mathrm{O}$ production was

360 mainly derived from $\mathrm{SOM}$ in peat. Ammonium and $\mathrm{NO}_{3}{ }^{-}$concentrations in soil in bare

361 treatments were lower than in the conventional treatments. In addition, $\mathrm{CO}_{2}$ flux in

362 conventional treatment in CL-A and CL-C, in which high $\mathrm{N}_{2} \mathrm{O}$ fluxes were observed, was

363 significantly correlated with $\mathrm{N}_{2} \mathrm{O}$ flux (Table 4). Therefore, the limiting factor of $\mathrm{N}_{2} \mathrm{O}$

364 production is the decomposition of SOM in peat. After decomposition of SOM, mineralized 
365 organic $\mathrm{N}$ was possibly nitrified and denitrified quickly to $\mathrm{N}_{2} \mathrm{O}$. Takakai et al. (2007) reported

$366 \mathrm{CO}_{2}$ flux in conventional treatment during the rainy season in the same plot of our study field 367 was significantly higher than during the dry season. In addition, there were no significant 368 differences in $\mathrm{CO}_{2}$ emission between conventional and bare treatments in all plots due to the 369 high decomposition rate of SOM (Takakai et al. 2007). This indicated that decomposition of $370 \mathrm{SOM}$ in peat was accelerated in rainy season and production of $\mathrm{CO}_{2}$ was mainly induced by 371 the decomposition of SOM, but not root respiration. Nitrous oxide flux tended to increase 372 with increasing $\mathrm{CO}_{2}$ flux in bare treatment in CL-A and CL-B. Thus, $\mathrm{N}_{2} \mathrm{O}$ production might 373 be closely influenced by the decomposition of SOM in peat. Also, $\mathrm{N}_{2} \mathrm{O}$-producing bacteria or 374 fungi (e.g. Janthinobacterium spp., Fusarium oxysporum, and Neocosmospora vasinfecta) 375 probably were important decomposers of peat during the rainy season (Yanai et al. 2007; 376 Hashidoko et al. 2008).

\section{Nitrous oxide emission in agricultural peat land}

379 Because there were no significant differences in $\mathrm{N}_{2} \mathrm{O}$ flux between conventional and bare 380 treatments in CL-A, CL-B, and CL-C (Table 2), increase in annual $\mathrm{N}_{2} \mathrm{O}$ emission could not be 381 due to increase in annual fertilizer $\mathrm{N}$ application rate. Thus, the correlation between annual $382 \mathrm{~N}_{2} \mathrm{O}$ emission and annual fertilizer $\mathrm{N}$ application rate might indicate the influence of long383 term management on annual $\mathrm{N}_{2} \mathrm{O}$ emission. Highest mean total $\mathrm{N}$ application in conventional 384 treatment in CL-A among the study plots indicated large amount of $\mathrm{N}$ fertilizer might have 385 been applied for long time in CL-A compared with those in other plots. Management or 386 history of cultivation prior to this study would change the quality of peat and characteristics 387 of microorganisms. Though there was no referable study on tropical agricultural peatland, 388 study on boreal organic soil in Finland, Maljanen et al. (2003) reported difference in annual $389 \mathrm{~N}_{2} \mathrm{O}$ emission between in adjusted forested and cultivated peatlands. In addition, application 
390 of organic and chemical fertilizer improved the nutrient ( $\mathrm{N}$, phosphorous, and potassium)

391 levels in soil over a 23-year period under a wheat-wheat-maize cropping system on a silt loam

392 soil in China (Su et al. 2006). Zhong et al. (2010) reported long-term application of chemical

393 and organic fertilizer to mineral soil collected in Jiangxi Province, China changed soil quality

394 and microbial community and diversity. Klemedtsson et al. (2005) reported that when soil

$395 \mathrm{C}: \mathrm{N}$ ratio of peat in boreal forests in Sweden decreased from 90 to 13 , mean annual $\mathrm{N}_{2} \mathrm{O}$

396 emission increased from 0.05 to $30 \mathrm{~kg} \mathrm{~N} \mathrm{ha}^{-1} \mathrm{yr}^{-1}$. There were few differences in soil C:N

397 ratio and soil $\mathrm{pH}$ among our study sites (Takakai et al. 2006). Thus, the influence of soil C:N

398 ratio and soil $\mathrm{pH}$ on $\mathrm{N}_{2} \mathrm{O}$ emission were not clear. However, as reported by Klemedtsson et al.

399 (2005), quality of peat and cultivation history may be a good indicator for the estimation of

$400 \mathrm{~N}_{2} \mathrm{O}$ emission from agricultural peat soil in tropical region.

401 Annual $\mathrm{N}_{2} \mathrm{O}$ emissions from conventional treatment in CL-A, CL-B, and CL-C, in which

402 fertilizers were applied, ranged from 12.6 to $698 \mathrm{~kg} \mathrm{~N} \mathrm{ha}^{-1} \mathrm{yr}^{-1}$ (Table 5). These values of

403 annual $\mathrm{N}_{2} \mathrm{O}$ emissions were greater than annual $\mathrm{N}_{2} \mathrm{O}$ emission $\left(0.1-56 \mathrm{~kg} \mathrm{~N} \mathrm{ha}^{-1} \mathrm{yr}^{-1}\right)$ from

404 boreal and temperate peat soils (Kasimir-Klemedtsson et al. 1997; Maljanen et al. 2003;

405 2004; Regina et al. 2004), and other $\mathrm{N}_{2} \mathrm{O}$ emission values (0.9-6.4 $\left.\mathrm{kg} \mathrm{N} \mathrm{ha}^{-1} \mathrm{yr}^{-1}\right)$ from

406 mineral soil reviewed and summarized by Bouwman et al. (2002). Furthermore, annual $\mathrm{N}_{2} \mathrm{O}$

407 emissions in this study were also greater than $\mathrm{N}_{2} \mathrm{O}$ emissions from tropical agricultural peat

408 soil in South Kalimantan, Indonesia (-1.1-2.03 $\mathrm{kg} \mathrm{N}$ ha $^{-1} \mathrm{yr}^{-1}$, Hadi et al. 2005; Inubushi et al.

409 2003) and Sarawak, Malaysia (1.2-3.3 $\mathrm{kg} \mathrm{N} \mathrm{ha}^{-1} \mathrm{yr}^{-1}$, Melling et al. 2007). Therefore, annual

$410 \quad \mathrm{~N}_{2} \mathrm{O}$ emission from agricultural fields in our study field might be the highest value reported to

411 date. Absence of the difference in annual $\mathrm{N}_{2} \mathrm{O}$ emission between conventional and bare

412 treatment plots, except for in CL-B and CL-C from April 2005 to March 2006, suggested that

413 most of emitted $\mathrm{N}_{2} \mathrm{O}$ in conventional treatment derived from the decomposition of SOM.

414 Therefore, larger annual $\mathrm{N}_{2} \mathrm{O}$ emission compared with $\mathrm{N}_{2} \mathrm{O}$ emissions in those studies might 
415 be affected by factors other than the amount of $\mathrm{N}$ fertilizer application. The agricultural peat

416 lands in our study sites are cultivated generally three to four times a year. Fertilizer was

417 applied in each cultivation. Thus, cultivation practices in our study site were different than

418 that reported of tropical peatland where oil palms (Melling et al. 2007) and sago palm (Hadi

419 et al. 2005) were cultivated. Intensive cultivation with high $\mathrm{N}$ application on drained peat soil

420 may change the quality of peat suitable for $\mathrm{N}_{2} \mathrm{O}$ production by denitrification. Kasimir-

421 Klemedtsson et al. (2009) reported $\mathrm{N}_{2} \mathrm{O}$ emission peaked after soil cultivation, plowing and

422 harrowing in grassland on drained peatland in Sweden $\left(58^{\circ} 20^{\prime} \mathrm{N}, 13^{\circ} 30^{\prime} \mathrm{E}\right)$. The period of

423 cultivation on drained peat land possibly affects the $\mathrm{N}_{2} \mathrm{O}$ emission because the quality of peat

424 and microbial community changes gradually after drainage (Su et al. 2006; Zhong et al. 2010).

425 Hence, differences in history and management of cultivation may cause large variation of $\mathrm{N}_{2} \mathrm{O}$

426 emission from tropical agricultural peat soil. Currently, there are not many studies about $\mathrm{N}_{2} \mathrm{O}$

427 emission in agricultural fields on tropical peat soil. Additional research regarding $\mathrm{N}_{2} \mathrm{O}$

428 emission from agricultural fields on tropical peat soil, therefore, is needed because large

429 amounts of $\mathrm{N}_{2} \mathrm{O}$ likely have been emitted and will continue to be from peat soil after

430 deforestation and establishment of arable land on peat soil.

431 In our study site, most $\mathrm{N}_{2} \mathrm{O}$ was derived from the decomposition of SOM. Even when the

432 difference in annual $\mathrm{N}_{2} \mathrm{O}$ emission was detected, the ratio of $\mathrm{N}_{2} \mathrm{O}$ emission induced by

433 fertilizer $\mathrm{N}$ and derived from SOM decomposition was almost equal (48-58.6\%). Since annual

$434 \mathrm{~N}_{2} \mathrm{O}$ emission in agricultural tropical peat land was higher than that in a natural forest, a

435 regenerated forest after burning, and a burned forest located close to our study site, $\mathrm{N}_{2} \mathrm{O}$

436 emission derived from SOM might be influenced by cultivation or land-use change from

437 natural forest to agricultural field. Indeed, the $\mathrm{N}_{2} \mathrm{O}$ emission factor induced by the cultivation

438 in tropical peat soil (16 $\left.\mathrm{kg} \mathrm{N} \mathrm{ha}^{-1} \mathrm{yr}^{-1}\right)$ estimated by IPCC (2006) was calculated using the

439 data in boreal peat soil $\left(8 \mathrm{~kg} \mathrm{~N} \mathrm{ha}^{-1} \mathrm{yr}^{-1}\right)$. However, estimated $\mathrm{N}_{2} \mathrm{O}$ emission originated from 
440 decomposition of SOM exceeded the value provided from IPCC (2007), whereas $\mathrm{N}_{2} \mathrm{O}$

441 emission derived from SOM in other agricultural peat soil reported by Melling et al. (2007)

442 and Hadi et al. (2005) might be lower because $\mathrm{N}_{2} \mathrm{O}$ emissions from those study site were

443 lower than $4 \mathrm{~kg} \mathrm{~N} \mathrm{ha}^{-1} \mathrm{yr}^{-1}$ despite application of $\mathrm{N}$ fertilizer at those sites. This indicated that

444 the $\mathrm{N}_{2} \mathrm{O}$ emission derived from decomposition of SOM in tropical agricultural peat soil might

445 vary widely. Thus, additional research on $\mathrm{N}_{2} \mathrm{O}$ emission in tropical agricultural peat soil is

446 needed to provide a more accurate value of emission factor for the cultivation in tropical peat

447 soil, its uncertainty, and to determine the factors influencing its variation.

448 The $\mathrm{EF}_{\mathrm{F}}$ value of this study (0-3.59\%) was smaller than the range reported by Takakai et al.

449 (2006) (1.8-36 \%) in our study field. Because Takakai et al. (2006) used $\mathrm{N}_{2} \mathrm{O}$ emission values

450 from $\mathrm{GL}$ as the estimate for $\mathrm{N}_{2} \mathrm{O}$ emission in CL-A, CL-B, and CL-C, EF $F_{\mathrm{F}}$ may have been

451 overestimated due to spatial variation of $\mathrm{N}_{2} \mathrm{O}$ emission among the sites. However, the $\mathrm{EF}_{\mathrm{F}}$

452 values in this study were similar or higher than the $1.00 \%$ value reported by IPCC (2006).

453 Akiyama et al. (2006) summarized published data and reported that $\mathrm{EF}_{\mathrm{F}}$ in well- and poorly

454 drained soil were 0.32 and $1.40 \%$, respectively. Bouwman (1996) reported $\mathrm{EF}_{\mathrm{F}}$ of chemical

455 and organic fertilizer ranged from 0.1 to $1.6 \%$ on mineral soil. Thus, $\mathrm{EF}_{\mathrm{F}}$ values in our study

456 were similar or slightly higher than other agricultural fields on mineral soil. On the other hand,

$457 \mathrm{EF}_{\mathrm{F}}$, on dry and wet Histosols in Netherlands were 4.21 and $1.38 \%$, respectively (Van Beek

458 et al. 2010). Although more work is needed to normalize $\mathrm{EF}_{\mathrm{F}}$ values in agricultural peat land

459 in tropical regions, $\mathrm{EF}_{\mathrm{F}}$ value in Histosols may be higher than in mineral soils. 


\section{ACKNOWLEDGMENTS}

461 The authors would like to thank Dr Hanny Wijaya (Bogor Agricultural University) and the 462 staffs in the University of Palangka Raya (Tony Wahyudi, Ledy, Logah, Paty, Ube) for their 463 support during our research. Also, we appreciate to Professor Takashi Hirano (Hokkaido 464 University) for providing climatic data. This study was partly supported by the JSPS-LIPI 465 Core University Program and a Japanese Grant-in-Aid for Science Research from the 466 Ministry of Education, Culture, Sports, Science and Technology (No. 13574012). Also, this 467 study was financially supported by the Global Environmental Research Program of the 468 Ministry of the Environment of Japan (No. S-2). 
469

470 Akiyama H, Yan X, Yagi K 2006: Estimations of emission factors for fertilizer-induced direct 471

472

(8)

\section{REFERENCES} $\mathrm{N}_{2} \mathrm{O}$ emissions from agricultural soils in Japan: Summary of available data. Soil Sci. Plant Nutr, 52, 774-787.

Alexander M 1977: Introduction to Soil Microbiology, 2nd edn. Wiley, New York.

Andriesse JP 1988: Nature and Management of Tropical Peat Soils. FAO Soils Bulletin 59, Food and Agriculture Organization of the United Nations, Rome.

476 Bouwman AF 1996: Direct emission of nitrous oxide from agricultural soils. Nutr. Cycling Agroecosys., 46, 53-70. fields: Summary of available measurement data. Glob. Biogeochem. Cycles, 16, doi:10.1029/2001GB001812.

Bremner JM 1997: Sources of nitrous oxide in soils. Nutr. Cycling Agroecosys., 49, 7-16.

Couwenberg J, Dommain R, Joosten H 2009: Greenhouse gas fluxes from tropical peatlands in south-east Asia. Glob Change Biol., 16, 1715-1732.

Dannenmann M, Butterbach-Bahl K, Gasche R, Willibald G, Papen H 2008: Dinitrogen emissions and the $\mathrm{N}_{2}: \mathrm{N}_{2} \mathrm{O}$ emission ratio of a Rendzic Leptosol as influenced by $\mathrm{pH}$ and forest thinning. Soil Biol. Biochem., 40, 2317-2323.

491 Hadi A, Inubushi K, Furukawa Y, Purnomo E, Rasmadi M, Tsuruta H 2005; Greenhouse gas 492 emissions from tropical peatlands of Kalimantan, Indonesia. Nutr. Cycling Agroecosys., 71, 73-80. 
494 Hashidoko Y, Takakai F, Toma Y, Darung U, Melling L, Tahara S, Hatano R 2008: Emergence 495 and behaviors of acid-tolerant Janthinobacterium sp. that evolves $\mathrm{N}_{2} \mathrm{O}$ from 496 deforested tropical peatland. Soil Biol. Biochem., 40, 116-125.

497 Hirano T, Segah H, Limin S, June T, Tuah SJ, Kusin K, Hirata R, Osaki M 2005: Energy 498 balance of a tropical peat swamp forest in Central Kalimantan, Indonesia. Phyton, 45, $499 \quad 67-71$.

500 Hirano T, Segah H, Harada T, Limin S, June T, Hirata R, Osaki M 2007: Carbon dioxide 501 balance of a tropical peat swamp forest in Kalimantan, Indonesia. Glob. Change $502 \quad$ Biol., 13, 412-425.

503 Hooijer A, Silvius M, Wo“sten H, Page S 2006: $P E A T-C_{2}$-assessment of $\mathrm{CO}_{2}$ emissions 504 from drained peatlands in SE Asia. Delft Hydraulics report Q3943, pp.36.

505 IPCC 1995: Climate Change 1995: The Science of Climate Change. Contribution of Working 506 Group I to the Second Assessment Report of the Intergovernmental Panel on Climate 507 Change. Eds JT Houghton, LG Meira Filho, BA Callander, N Harris, A Kattenberg $508 \quad$ and K Maskell. Cambridge University Press, Cambridge.

509 IPCC 2006: $\mathrm{N}_{2} \mathrm{O}$ emissions from managed soils, and $\mathrm{CO}_{2}$ emissions from lime and urea 510 application. In 2006 IPCC Guidelines for National Greenhouse Gas Inventories. Vol. 511 4. Agriculture, Forestry and Other Land Use. Available via http://www.ipcc$512 \quad$ nggip.iges.or.jp/public/2006gl/vol4.htm. (accessed 15.07.10)

513 IPCC 2007: Climate Change 2007: The Physical Science Basis. Cambridge University Press, $514 \quad$ Cambridge.

515 Inubushi K, Furukawa Y, Hadi A, Purnomo E, Tsuruta H, 2003: Seasonal changes of $\mathrm{CO}_{2}$, $516 \quad \mathrm{CH}_{4}$ and $\mathrm{N}_{2} \mathrm{O}$ fluxes in relation to land-use change in tropical peatlands lacated in 517 coastal area of South Kalimantan. Chemosphere, 52, 603-608.

518 Kasimir-Klemedtsson A, Klemedtsson L, Berglung K, Martikainen P, Silvola L, Oenema O 
1997: Greenhouse gas emissions from farmed organic soils: a review. Soil Use Manag., 13, 245-250.

521 Kasimir-Klemedtsson Å, Weslien P, Klemedtsson L 2009: Methane and nitrous oxide fluxes from a farmed Swedish Histsol. Europ. J Soil Sci., 60, 321-331.

523 Klemedtsson L, Arnold KV, Weslien P, Gundersen P, 2005: Soil CN ratio as a scalar parameter 524 to predict nitrous oxide emissions. Glob. Change Biol., 11, 1142-1147.

525 Kusa K, Sawamoto T, Hu R, Hatano R 2008: Comparison of the closed-chamber and gas 526 concentration gradient methods for measurement of $\mathrm{CO}_{2}$ and $\mathrm{N}_{2} \mathrm{O}$ fluxes in two upland field soils. Soil Sci. Plant Nutr., 54, 777-785.

529

Maljanen M, Liikanen A, Silvola J, Martikaine PJ 2003: Nitrous oxide emissions from boreal organic soil under different land-use. Soil Biol. Biochem., 35, 689-700.

530 Maljanen M, Komulainen VM, Hytönen L, Martikaine PJ, Laine J 2004: Carbon dioxide, 531 nitrous oxide and methane dynamics in boreal organic agricultural soils with different soil management. Soil Biol. Biochem., 36, 1801-1808.

Maltby E, Immirzi P 1993: Carbon dynamics in peatlands and other wetland soils. Regional 534 and global perspectives. Chemosphere, 27, 999-1023.

535 Melling L, Hatano R, Goh KJ 2007: Nitrous oxide emissions from three ecosystems in $536 \quad$ tropical peatland of Sarawak, Malaysia. Soil Sci. Plant Nutr., 53, 792-805.

537 Morishita T, Hatano R, Desyatkin RV, 2003: $\mathrm{CH}_{4}$ flux in an alas ecosystem formed by forest 538 disturbance near Yakutsk, eastern Siberia, Russia. Soil Sci. Plant Nutr., 49, 369-377.

539 Mosier AR, Kroeze C, Nevison C, Oenema O, Seitzunger S, Van Cleemput O 1998: Closing 540 the global $\mathrm{N}_{2} \mathrm{O}$ budget: nitrous oxide emissions through the agricultural nitrogen 541 cycle. OECD/IPCC/IEA phase development of IPCC guidelines for national 542 greenhouse gas inventory methodology, Nutr. Cycling Agroecosys, 52, 225-248.

543 Muhanmad NZ, Rieley JO 2002: Management of tropical peatlands in Indonesia: Mega 
reclamation project in Central Kalimantan. In Peatlands for People, Natural Resources Function and Sustainable Management. Proceedings of the International Symposium on Tropical Peatlands, 22-23 August 2001, Jakarta, Indonesia, eds JO Rieley and SE Page, pp. 155-160. BPPT and Indonesian Peat Association, Jakarta.

Nakano T, Sawamoto T, Morishita T, Inoue G., Hatano R 2004: A comparison of regression 549 methods for estimating soil-atmosphere diffusion gas fluxes by a closed-chamber technique. Soil Biol. Biochem., 36, 107-113.

Page SE, Slegert F, Rieley JO, Boehm HDV, Zaya A, Limin S 2002: The amount of carbon released from peat and forest fires in Indonesia during 1997. Nature, 420, 61-65. ethylene and ethane in air and their measurement. J Soil Sci., 33, 175-184.

555 Ravishankara AR, Daniel JS, Portmann RW 2009: Nitrous oxide $\left(\mathrm{N}_{2} \mathrm{O}\right)$ : The dominanat ozone-depleting substance emitted in the 21 st century. Nature, 326, 123-125.

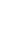

558

559

560

Shoun H, Kim DH, Uchiyama H, Sugiyama J 2006: Denitrification by fungi. FEMS Microbio. Finland. Europ. J Soil Sci., 55, 591-599.

561 Su YZ, Wnag F, Suo DR, Zhang ZH, Du MW 2006: Long-term effect of fertilizer and manure 562

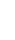
566 60

$$
\text { Lett., 94, 277-281. }
$$

$$
\begin{aligned}
& \text { application on soil-carbon sequestration and soil fertility under the wheat-wheat- } \\
& \text { maize cropping system in northwest China. Nutr. Cycling Agroecosys., 75, 285-295. }
\end{aligned}
$$

564 Takakai F, Morishita T, Hashidoko Y, Darung U, Kuramochi K, Dohong S, Limin SH, Hatano

565 R 2006: Effects of agricultural land-use change and forest fire on $\mathrm{N}_{2} \mathrm{O}$ emission from tropical peatlands, Central Kalimantan, Indonesia. Soil Sci. Plant Nutr., 52, 662-674.

567 Takakai F, Toma Y, Morishita T, Darung U, Dohong S, Limin SH., Hatano R 2007:

568 Contribution of organic matter decomposition and root respiration to $\mathrm{CO}_{2}$ emissions 
569

570

571

572

573

574

575

576

577

578

579

580

581

582

583

584

585

586

587

588

589

590

591

592

593

from cultivated tropical peatland in Central Kalimantan, Indonesia. In: Proceedings of the International Workshop on Human Dimension of Tropical Peatland under Global Environmental Changes, December 8-9, 2004, Bogor, Indonesia (eds Iswandi A, Wijaya HC, Guhardja S, Segah H, Iwakuma T, Osaki M), pp. 101-111. Bogor Agricultural University/Hokkaido University, Bogor/Hokkaido.

Terry RE, Tate RL, Duxbury JM 1981: Nitrous oxide emissions from drained, cultivated organic soils of South Florida. J Air Pollut. Contr. Assoc., 31, 1173-1176.

Tiedje JM 1994: Denitrifiers. In: Weaver, R.W.(ED), Methods of Soil Analysis. Part 2. SSSA Book Series 5. SSSA, Madison, MI, pp.245-257.

Toma Y, Kimura SD, Yamada H, Hirose Y, Fujiwara K, Kusa K, Hatano R 2010: Effects of environmental factors on temporal variation in annual carbon dioxide and nitrous oxide emissions from an unfertilized bare field on Gray Lowland soil in Mikasa, Hokkaido, Japan. Soil Sci. Plant Nutr., 56, 663-675.

Toma Y, Hatano R 2007: Effect of crop residue C:N ratio on $\mathrm{N}_{2} \mathrm{O}$ emissions from Gray Lowland soil in Mikasa, Hokkaido, Japan. Soil Sci. Plant Nutr., 53, 198-205.

Van Beek CL, Pleijiter M, Jacpbs CMJ, Velthof GL, van Groenigen JW, Kuikman PJ 2010: Emissions of $\mathrm{N}_{2} \mathrm{O}$ from fertilized and grazed grassland on organic soil in relation to groundwater level. Nutr. Cycling Agroecosys., 86, 331-340.

Van-Cleemput O, Vermoesen A, Degroot CJ, Vanryckeghem K 1994: Nitrous oxide emission out of grassland. Environ. Monit. Assess., 31, 145-152.

Velthof GL, Oenema O 1995: Nitrous oxide fluxes from grassland in the Netherlands .1. Statistical analysis of flux-chamber measurements. Europ. J Soil Sci., 46, 533-540.

Wanner-Riddle C, Furon A, Mclaughlin NL, Lee I, Barbeau J, Jayasundara S, Parkin G, Bertoldi P, Warland J 2007: Intensive measurement of nitrous oxide emissions from a corn-soybean-wheat rotation under two contrasting management systems over 5 
1

2

3

4

5

6

7

8

9

10

11

12

13

14

15

16

17

18

19

20

21

22

23

24

25

26

27

28

29

30

31

32

33

34

35

36

37

38

39

40

41

42

43

44

45

46

47

48

49

50

51

52

53

54

55

56

57

58

59

60

594 years. Glob. Change Biol., 13, 1722-1736.

595 Yanai Y, Toyota K, Morishita T, Takakai F, Hatano R, Limin SH, Darung U, Dohong S 2007:

596 Fungal $\mathrm{N}_{2} \mathrm{O}$ production in an arable peat soil in Central Kalimantan, Indonesia. Soil $597 \quad$ Sci. Plant Nutr, 53, 806-811.

598 Zhong W, Gu I, Wnag W, Zhang B, Lin X, Huang Q, Shen W 2010: The effects of mineral 599 fertilizer and organic manure on soil microbial community and diversity. Plant Soil, $600 \quad 326,511-522$.

601 


\section{FIGURE LEGENDS}

603 Fig. 1 Seasonal variation in air temperature and precipitation (a), water table (b), soil 604 temperature (c), water filled pore space (WFPS) (d), ammonium $\left(\mathrm{NH}_{4}{ }^{+}\right)$, nitrate $\left(\mathrm{NO}_{3}{ }^{-}\right)$ 605 concentrations $(e)$, and carbon dioxide $\left(\mathrm{CO}_{2}\right)(\mathrm{f})$ and nitrous oxide $\left(\mathrm{N}_{2} \mathrm{O}\right)$ fluxes $(\mathrm{g})$ in 606 cropland A (CL-A) in Central Kalimantan, Indonesia. Conventional and Bare represents 607 conventional cultivation treatment and bare treatment, respectively. Ammonium and $\mathrm{NO}_{3}{ }^{-}$ 608 concentrations (e) are only in conventional treatment. Error bars are standard deviation. 609

610 Fig. 2 Seasonal variation in air temperature and precipitation (a), water table (b), soil 611 temperature (c), water filled pore space (WFPS) (d), ammonium $\left(\mathrm{NH}_{4}{ }^{+}\right)$, nitrate $\left(\mathrm{NO}_{3}{ }^{-}\right)$ 612 concentrations $(e)$, and carbon dioxide $\left(\mathrm{CO}_{2}\right)(\mathrm{f})$ and nitrous oxide $\left(\mathrm{N}_{2} \mathrm{O}\right)$ fluxes $(\mathrm{g})$ in 613 cropland B (CL-B) in Central Kalimantan, Indonesia. Conventional and Bare represents 614 conventional cultivation treatment and bare treatment, respectively. Ammonium and $\mathrm{NO}_{3}{ }^{-}$ 615 concentrations (e) are only in conventional treatment. Error bars are standard deviation.

617 Fig. 3 Seasonal variation in air temperature and precipitation (a), water table (b), soil 618 temperature (c), water filled pore space (WFPS) (d), ammonium $\left(\mathrm{NH}_{4}{ }^{+}\right)$, nitrate $\left(\mathrm{NO}_{3}{ }^{-}\right)$ 619 concentrations $(e)$, and carbon dioxide $\left(\mathrm{CO}_{2}\right)(\mathrm{f})$ and nitrous oxide $\left(\mathrm{N}_{2} \mathrm{O}\right)$ fluxes $(\mathrm{g})$ in 620 cropland C (CL-C) in Central Kalimantan, Indonesia. Conventional and Bare represents 621 conventional cultivation treatment and bare treatment, respectively. Ammonium and $\mathrm{NO}_{3}{ }^{-}$ 622 concentrations (e) are only in conventional treatment. Error bars are standard deviation. 623

624 Fig. 4 Seasonal variation in air temperature and precipitation (a), water table (b), soil 625 temperature (c), water filled pore space (WFPS) (d), ammonium $\left(\mathrm{NH}_{4}{ }^{+}\right)$, nitrate $\left(\mathrm{NO}_{3}{ }^{-}\right)$ 626 concentrations (e), and carbon dioxide $\left(\mathrm{CO}_{2}\right)(\mathrm{f})$ and nitrous oxide $\left(\mathrm{N}_{2} \mathrm{O}\right)$ fluxes $(\mathrm{g})$ in 
1

3 4

5

6

7

8 9

10 11 12

627 grassland (GL) in Central Kalimantan, Indonesia. Error bars are standard deviation.

628

629 Fig. 5 Relationships between logarithmic value of the ratio of nitrous oxide $\left(\mathrm{N}_{2} \mathrm{O}\right)$ flux and 630 soil nitrate $\left(\mathrm{NO}_{3}{ }^{-}\right)$concentration $\left(\mathrm{Ln}\left(\mathrm{N}_{2} \mathrm{O}\right.\right.$ flux / $\left.\left.\mathrm{NO}_{3}{ }^{-}\right)\right)$against water filled pore space 631 (WFPS) in conventional treatment in cropland A (CL-A), cropland B (CL-B), cropland C 632 (CL-C), and grassland (GL) in Central Kalimantan, Indonesia. 
Table 1 Amount of nitrogen fertilizer application rate in cropland A (CL-A), B (CL-B), C (CL-C) from April 2002 to March 2007 in Central Kalimantan, Indonesia. Data from April 2002 to March 2004 were cited from Takakai et al. (2006).

\begin{tabular}{|c|c|c|c|c|c|c|c|c|c|}
\hline \multirow{3}{*}{ Year } & \multicolumn{9}{|c|}{ Nitrogen fertilizer application rate $\left(\mathrm{kg} \mathrm{N} \mathrm{ha}^{-1} \mathrm{yr}^{-1}\right)$} \\
\hline & \multicolumn{3}{|c|}{ CL-A } & \multicolumn{3}{|c|}{ CL-B } & \multicolumn{3}{|c|}{ CL-C } \\
\hline & Chemica & Organic & Total & Chemic & rgani & Total & Chemic & Organic & Total \\
\hline $2002 / 4-2003 / 3$ & 818 & 180 & 998 & 760 & 40 & 800 & 1,098 & 180 & 1,278 \\
\hline $2003 / 4-2004 / 3$ & 545 & 120 & 665 & 853 & 100 & 953 & 665 & 120 & 785 \\
\hline $2004 / 4-2005 / 3$ & 1,378 & 180 & 1,558 & 633 & 140 & 773 & 1,011 & 196 & 1,207 \\
\hline $2005 / 4-2006 / 3$ & 1,505 & 120 & 1,625 & 460 & 184 & 644 & 945 & 120 & 1,065 \\
\hline $2006 / 4-2007 / 3$ & 1,458 & 180 & 1,638 & 0 & 0 & 0 & 945 & 120 & 1,065 \\
\hline $\begin{array}{c}\text { Average } \\
(2004 / 4-2007 / 3)\end{array}$ & 1,447 & 160 & 1,607 & 365 & 108 & 472 & 967 & 145 & 1,113 \\
\hline
\end{tabular}


Table 2 Statistical analysis of the difference in nitrous oxide $\left(\mathrm{N}_{2} \mathrm{O}\right)$ flux, soil temperature, and water filled pore space (WFPS) between conventional and bare treatments in cropland A (CL-A), cropland B (CL-B), and cropland C (CL-C) from April 2004 to March 2007 in Central Kalimantan, Indonesia. Nitrous oxide flux was converted to logarithm value. Difference in $\mathrm{N}_{2} \mathrm{O}$ was analyzed by Student's $t$-test and soil temperature or WFPS were analyzed by Mann-Whitney's $U$-test.

\begin{tabular}{|c|c|c|c|c|c|c|c|}
\hline & & \multicolumn{2}{|c|}{ CL-A } & \multicolumn{2}{|c|}{ CL-B } & \multicolumn{2}{|c|}{ CL-C } \\
\hline & & Conventio & Bare & Convention & Bare & Conventiona & Bare \\
\hline \multirow{5}{*}{$\mathrm{N}_{2} \mathrm{O}$ flux ${ }^{\S}$} & $n$ & & & \multicolumn{2}{|c|}{35} & \multicolumn{2}{|c|}{36} \\
\hline & Average & 0.87 & 0.91 & -3.14 & -3.15 & -1.39 & -1.46 \\
\hline & $s^{2}$ & \multicolumn{2}{|c|}{4.50} & \multicolumn{2}{|c|}{2.33} & \multicolumn{2}{|c|}{5.39} \\
\hline & $t$ & \multicolumn{2}{|c|}{0.04} & \multicolumn{2}{|c|}{0.02} & \multicolumn{2}{|c|}{0.06} \\
\hline & $P$ & \multicolumn{2}{|c|}{$>0.1$} & \multicolumn{2}{|c|}{$>0.1$} & \multicolumn{2}{|c|}{$>0.1$} \\
\hline \multirow{5}{*}{$\begin{array}{c}\text { Soil } \\
\text { temperature }\end{array}$} & $n$ & 35 & 35 & 35 & 35 & 35 & 35 \\
\hline & Median & 31.0 & 30.9 & 29.7 & 29.9 & 31.1 & 31.1 \\
\hline & $U$ & \multicolumn{2}{|c|}{616} & \multicolumn{2}{|c|}{526} & \multicolumn{2}{|c|}{652} \\
\hline & $z$ & \multicolumn{2}{|c|}{0.04} & \multicolumn{2}{|c|}{-1.02} & \multicolumn{2}{|c|}{0.46} \\
\hline & $P$ & \multicolumn{2}{|c|}{0.96} & \multicolumn{2}{|c|}{0.31} & \multicolumn{2}{|c|}{0.64} \\
\hline \multirow{5}{*}{ WFPS } & $n$ & 35 & 35 & 35 & 35 & 35 & 35 \\
\hline & Median & 62.1 & 59.6 & 62.6 & 64.3 & 71.3 & 72.3 \\
\hline & $U$ & \multicolumn{2}{|c|}{698} & \multicolumn{2}{|c|}{588} & \multicolumn{2}{|c|}{579} \\
\hline & $z$ & \multicolumn{2}{|c|}{1.00} & \multicolumn{2}{|c|}{-0.29} & \multicolumn{2}{|c|}{-0.39} \\
\hline & $P$ & \multicolumn{2}{|c|}{0.31} & \multicolumn{2}{|c|}{0.77} & \multicolumn{2}{|c|}{0.69} \\
\hline
\end{tabular}

$\S \mathrm{N}_{2} \mathrm{O}$ flux was converted to logarithm value 
Table 3 Net nitrous oxide $\left(\mathrm{N}_{2} \mathrm{O}\right)$ production rate in soil in conventional treatments in cropland A (CL-A), B (CL-B), C (CL-C), and grassland (GL) from April 2004 to March 2007 in Central Kalimantan, Indonesia.

\begin{tabular}{|c|c|c|c|c|c|c|c|c|c|c|c|c|}
\hline \multirow{2}{*}{$\begin{array}{l}\text { Depth } \\
\text { (cm) }\end{array}$} & \multicolumn{3}{|c|}{ CL-A } & \multicolumn{3}{|c|}{ CL-B } & \multicolumn{3}{|c|}{ CL-C } & \multicolumn{3}{|c|}{ GL } \\
\hline & Average & $\max$ & $\min$ & Average & $\max$ & $\min$ & Average & $\max$ & $\min$ & Average & $\max$ & $\min$ \\
\hline $2.5-7.5$ & 4.77 & 60.2 & -19.6 & 0.61 & 15.8 & -1.40 & 0.32 & 2.58 & -1.25 & 4.14 & 17.48 & -0.13 \\
\hline $7.5-15$ & 6.36 & 81.7 & -16.2 & -0.15 & 1.81 & -6.75 & 0.35 & 3.20 & -0.30 & -0.27 & 1.22 & -4.58 \\
\hline
\end{tabular}


Table 4 Spearman's rank correlation coefficients of nitrous oxide $\left(\mathrm{N}_{2} \mathrm{O}\right)$ flux and water table depth, soil temperature, water filled pore space (WFPS), ammonium $\left(\mathrm{NH}_{4}{ }^{+}\right)$and nitrate $\left(\mathrm{NO}_{3}{ }^{-}\right)$concentrations, or $\mathrm{CO}_{2}$ flux in conventional treatments from April 2004 to March 2007 in cropland A (CL-A), B (CL-B), and C (CL-C) and grassland (GL) in Central Kalimantan, Indonesia.

\begin{tabular}{lcccc}
\hline & CL-A & CL-B & CL-C & GL \\
\hline Water table depth $(\mathrm{cm})$ & -0.01 & 0.03 & $0.53^{* *}$ & 0.26 \\
Soil Temperature $\left({ }^{\circ} \mathrm{C}\right)$ & -0.04 & -0.18 & 0.15 & -0.12 \\
WFPS $(\%)$ & $0.59 * *$ & $0.52 * *$ & 0.18 & $0.66 * *$ \\
$\mathrm{NH}_{4}^{+}\left(\mathrm{mg} \mathrm{N} \mathrm{kg}^{-1}\right)$ & -0.13 & 0.11 & 0.08 & -0.28 \\
$\mathrm{NO}_{3}{ }^{-}\left(\mathrm{mg} \mathrm{N} \mathrm{kg}^{-1}\right)$ & -0.27 & $0.51 * *$ & $0.38^{* *}$ & 0.06 \\
$\mathrm{CO}_{2}$ flux $\left(\mathrm{g} \mathrm{C} \mathrm{m}^{-2} \mathrm{hr}^{-1}\right)$ & $0.34 *$ & 0.28 & $0.49^{* *}$ & 0.24 \\
\hline$* * P<0.01, * P<0.05$ & & & &
\end{tabular}


Table 5 Annual nitrous oxide $\left(\mathrm{N}_{2} \mathrm{O}\right)$ emission in conventional and bare treatments from 2002 to 2007 in cropland A (CL-A), B (CL-B), C (CL-C), and grassland (GL) in Central Kalimantan, Indonesia. Data of $\mathrm{N}_{2} \mathrm{O}$ emission from April 2002 to March 2004 were cited from Takakai et al. (2006). Values between parentheses indicate oneside $95 \%$ confidence interval. Asterisk showed there was significant difference in $\mathrm{N}_{2} \mathrm{O}$ emission between conventional and bare treatments at $5 \%$ significant level.

\begin{tabular}{|c|c|c|c|c|c|c|c|}
\hline \multirow{3}{*}{ Year } & \multicolumn{7}{|c|}{ Annual $\mathrm{N}_{2} \mathrm{O}$ emission $\left(\mathrm{kg} \mathrm{N} \mathrm{ha}^{-1} \mathrm{yr}^{-1}\right)$} \\
\hline & \multicolumn{2}{|c|}{ CL-A } & \multicolumn{2}{|c|}{ CL-B } & \multicolumn{2}{|c|}{ CL-C } & \multirow{2}{*}{$\frac{\mathrm{GL}}{\text { Conventional }}$} \\
\hline & Conventional & Bare & Conventional & Bare & Conventional & Bare & \\
\hline $2002 / 4-2003 / 3$ & $121(28.5)$ & - & $20.8(3.42)$ & - & $76.9(19.9)$ & - & $5.08(0.56)$ \\
\hline $2003 / 4-2004 / 3$ & $229(32.1)$ & - & $46.1(5.55)$ & - & $108(11.9)$ & - & $20.8(4.20)$ \\
\hline $2004 / 4-2005 / 3$ & $416(16.1)$ & - & $51.8(6.28)$ & - & $36.2(13.0)$ & - & $31.1(5.50)$ \\
\hline $2005 / 4-2006 / 3$ & $627(8.25)$ & $608(24.9)$ & $12.6(1.95)$ & $7.38(0.50)^{*}$ & $73.7(6.12)$ & $35.4(1.12)^{*}$ & $65.9(5.38)$ \\
\hline $2006 / 4-2007 / 3$ & $698(69.1)$ & $858(37.4)$ & $10.9(8.86)$ & $6.55(1.64)$ & $168(14.5)$ & $216(2.46)$ & $32.3(2.16)$ \\
\hline $\begin{array}{c}\text { Average } \\
(2004 / 4-2007 / 3)\end{array}$ & 580 & 733 & 25.1 & 6.96 & 92.5 & 126 & 43.1 \\
\hline
\end{tabular}



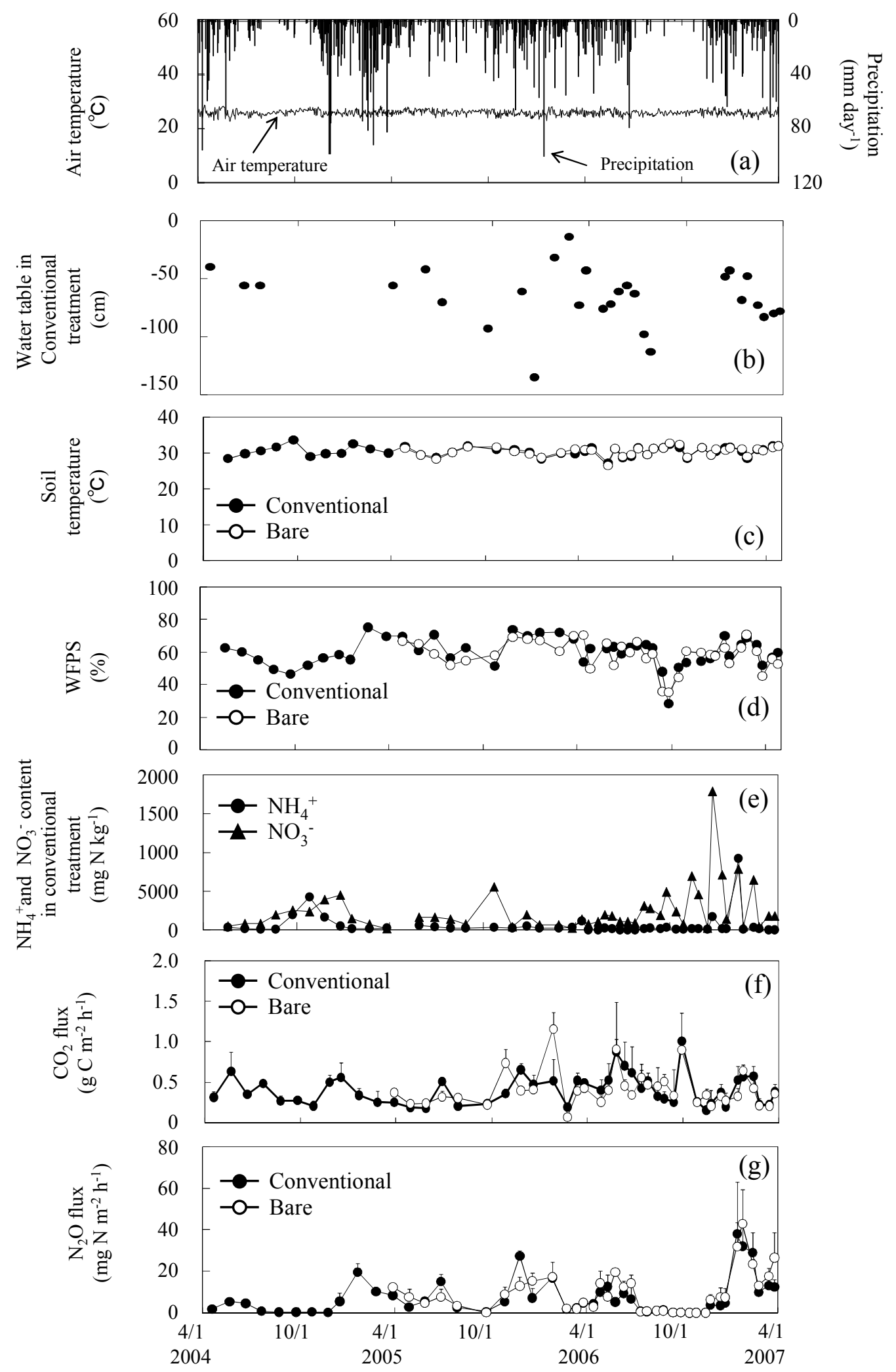

Fig. 1 Seasonal variation in air temperature and precipitation (a), water table (b), soil temperature (c), water filled pore space (WFPS) (d), ammonium $\left(\mathrm{NH}_{4}^{+}\right)$, nitrate $\left(\mathrm{NO}_{3}^{-}\right)$concentrations (e), and carbon dioxide $\left(\mathrm{CO}_{2}\right)(\mathrm{f})$ and nitrous oxide $\left(\mathrm{N}_{2} \mathrm{O}\right)$ fluxes $(\mathrm{g})$ in cropland $\mathrm{A}(\mathrm{CL}-\mathrm{A})$ in Central Kalimantan, Indonesia. Conventional and Bare represents conventional cultivation treatment and bare treatment, respectively. Ammonium and $\mathrm{NO}_{3}{ }^{-}$concentrations (e) are only in conventional treatment. Error bars are standard deviation. 

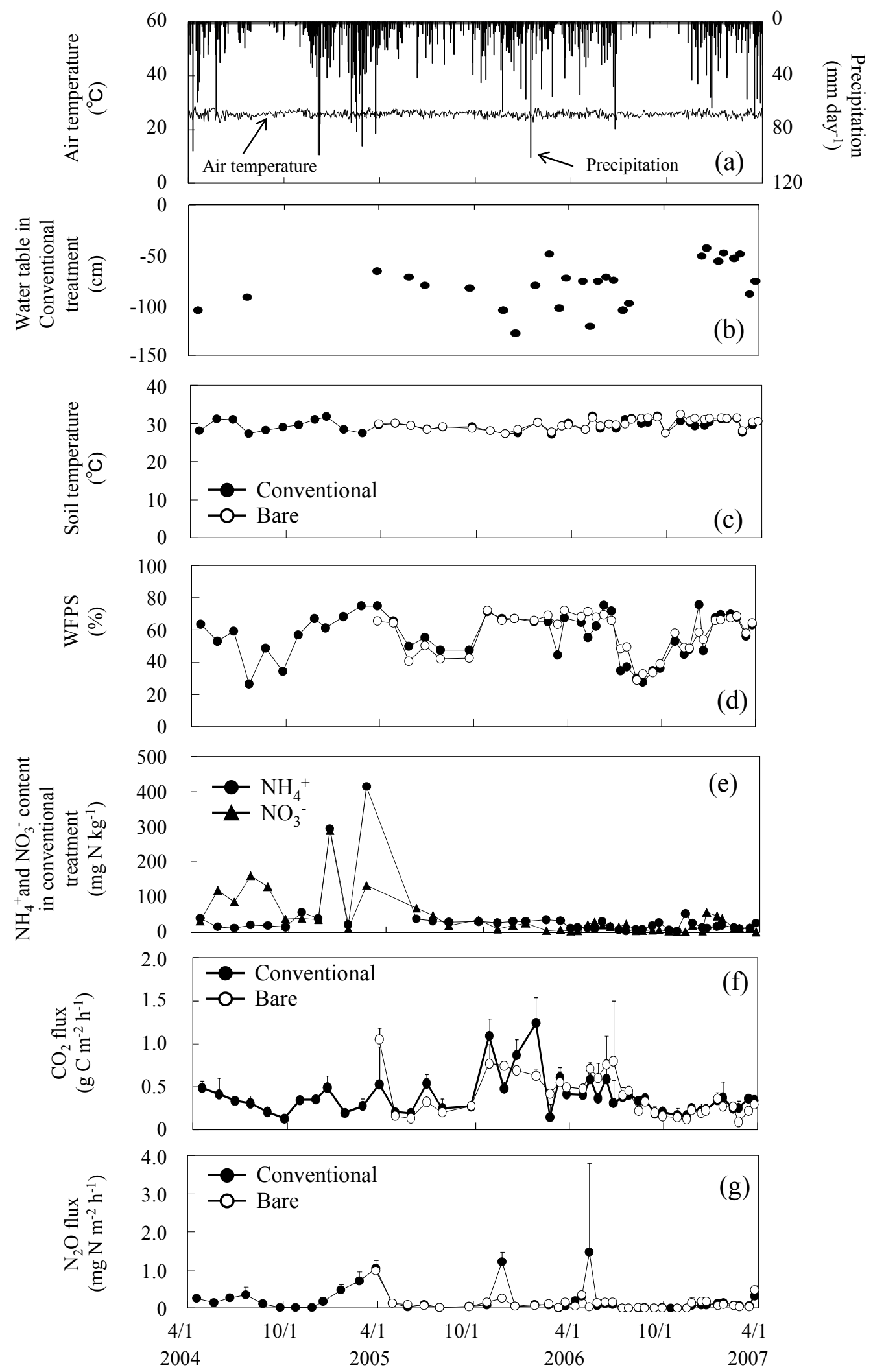

Fig. 2 Seasonal variation in air temperature and precipitation (a), water table (b), soil temperature (c), water filled pore space (WFPS) (d), ammonium $\left(\mathrm{NH}_{4}^{+}\right)$, nitrate $\left(\mathrm{NO}_{3}^{-}\right)$concentrations (e), and carbon dioxide $\left(\mathrm{CO}_{2}\right)(\mathrm{f})$ and nitrous oxide $\left(\mathrm{N}_{2} \mathrm{O}\right)$ fluxes $(\mathrm{g})$ in cropland $\mathrm{B}(\mathrm{CL}-\mathrm{B})$ in Central Kalimantan, Indonesia. Conventional and Bare represents conventional cultivation treatment and bare treatment, respectively. Ammonium and $\mathrm{NO}_{3}{ }^{-}$concentrations (e) are only in conventional treatment. Error bars are standard deviation. 

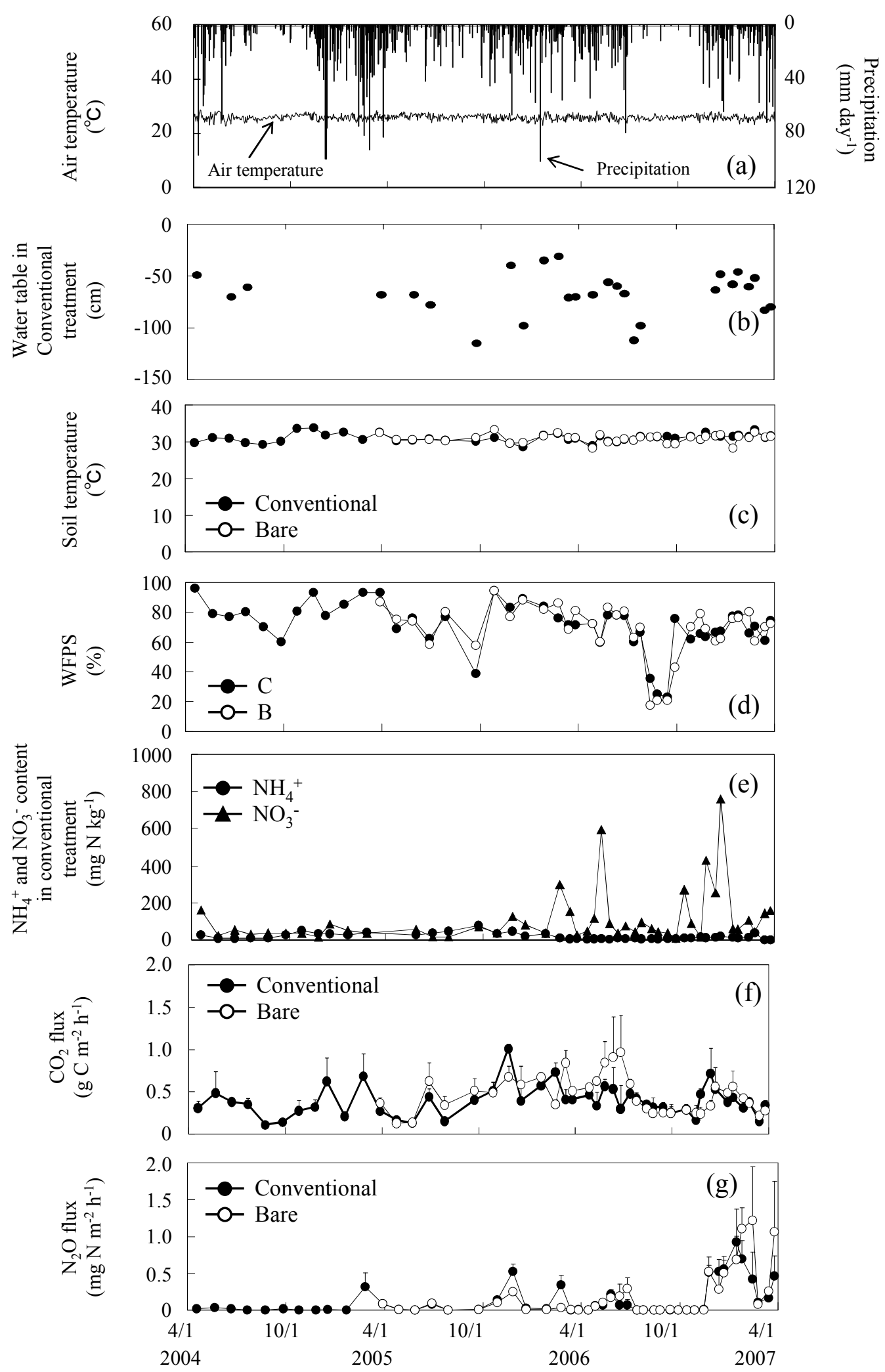

Fig. 3 Seasonal variation in air temperature and precipitation (a), water table (b), soil temperature (c), water filled pore space (WFPS) (d), ammonium $\left(\mathrm{NH}_{4}^{+}\right)$, nitrate $\left(\mathrm{NO}_{3}^{-}\right)$concentrations (e), and carbon dioxide $\left(\mathrm{CO}_{2}\right)$ (f) and nitrous oxide $\left(\mathrm{N}_{2} \mathrm{O}\right)$ fluxes $(\mathrm{g})$ in cropland $\mathrm{C}(\mathrm{CL}-\mathrm{C})$ in Central Kalimantan, Indonesia. Conventional and Bare represents conventional cultivation treatment and bare treatment, respectively. Ammonium and $\mathrm{NO}_{3}^{-}$concentrations (e) are only in conventional treatment. Error bars are standard deviation. 

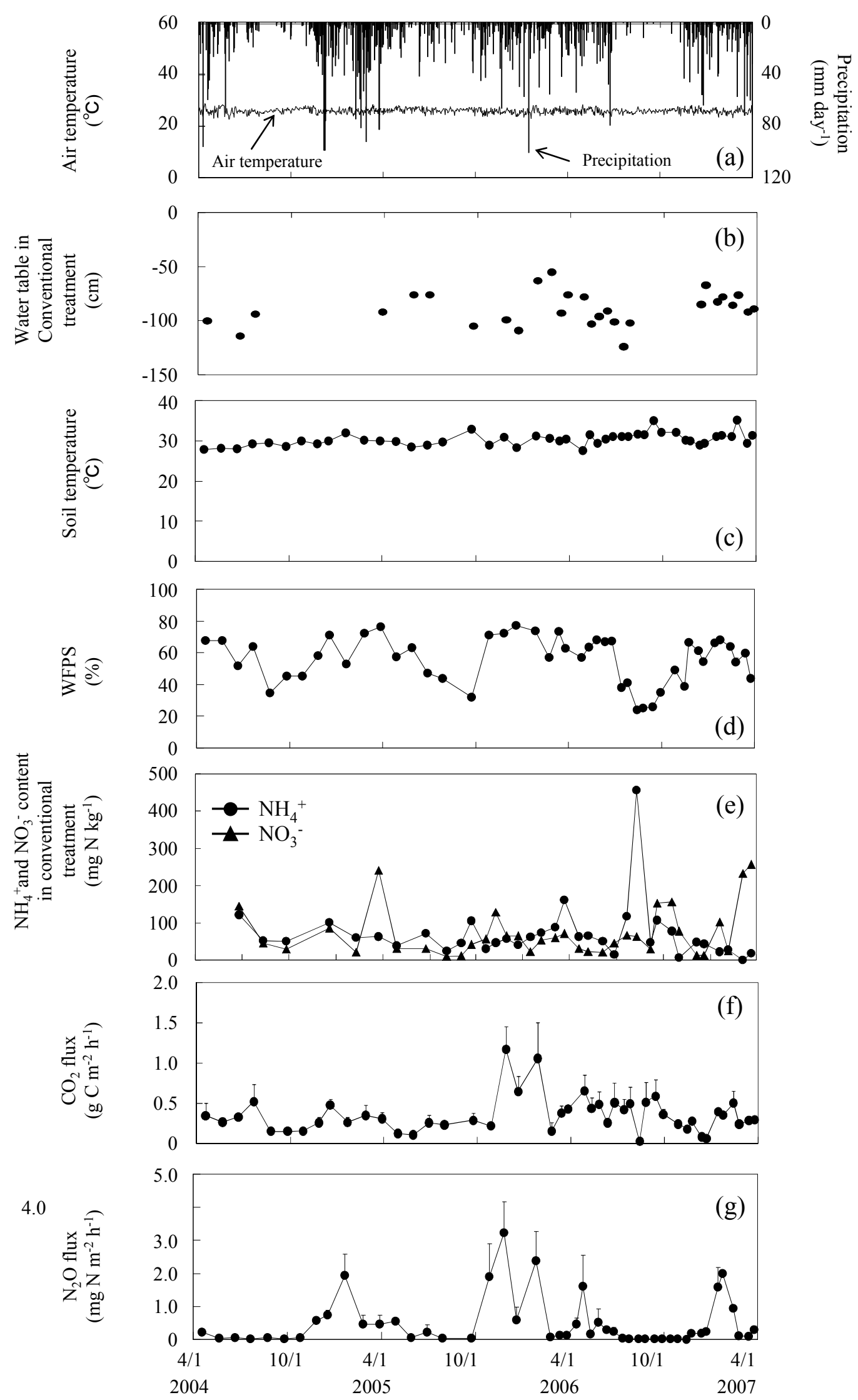

Fig. 4 Seasonal variation in air temperature and precipitation (a), water table (b), soil temperature (c), water filled pore space (WFPS) (d), ammonium $\left(\mathrm{NH}_{4}^{+}\right)$, nitrate $\left(\mathrm{NO}_{3}{ }^{-}\right)$ concentrations (e), and carbon dioxide $\left(\mathrm{CO}_{2}\right)(\mathrm{f})$ and nitrous oxide $\left(\mathrm{N}_{2} \mathrm{O}\right)$ fluxes $(\mathrm{g})$ in grassland (GL) in Central Kalimantan, Indonesia. Error bars are standard deviation. 


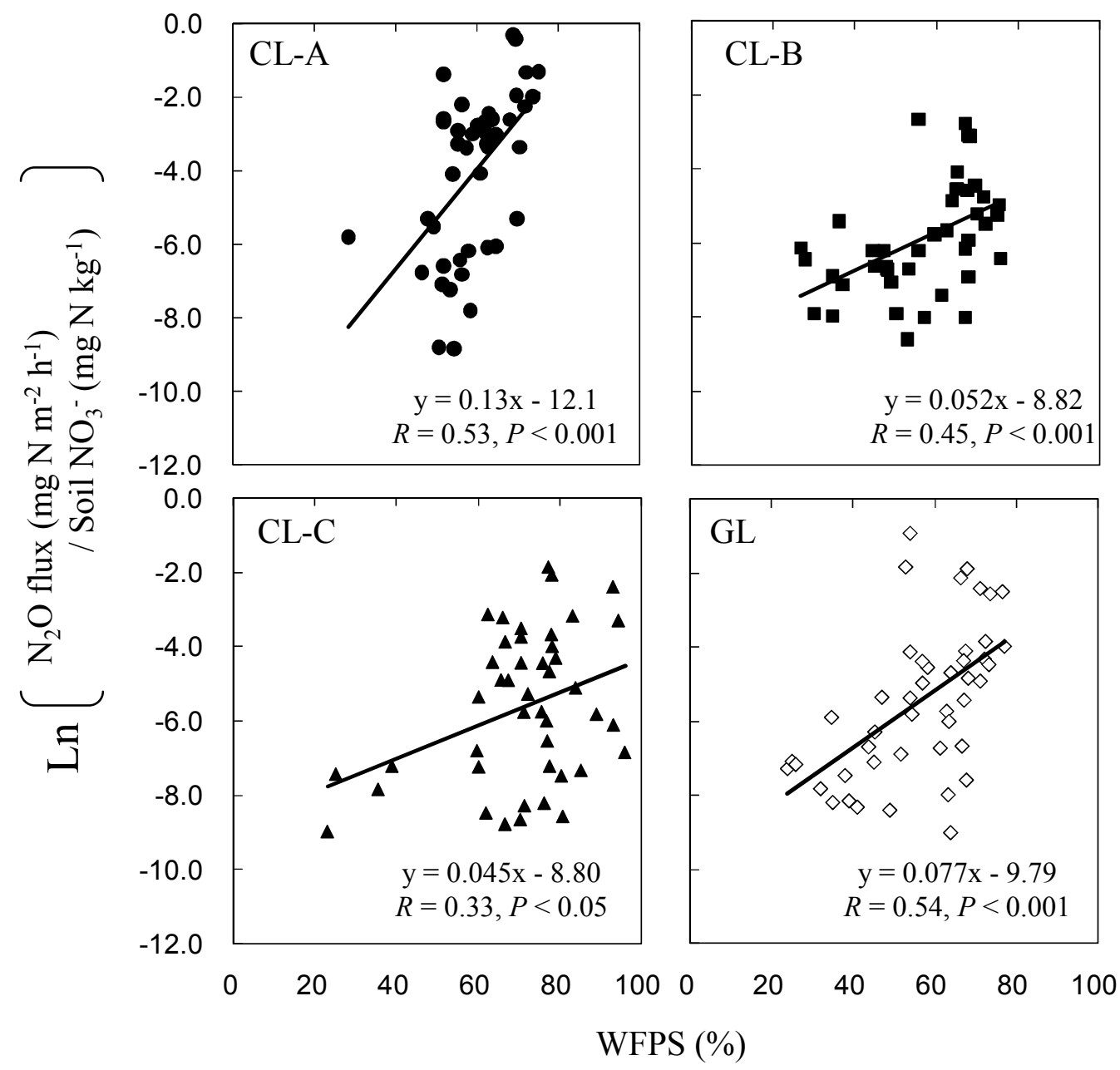

Fig. 5 Relationships between logarithmic value of the ratio of nitrous oxide $\left(\mathrm{N}_{2} \mathrm{O}\right)$ flux and soil nitrate $\left(\mathrm{NO}_{3}^{-}\right)$concentration $\left(\mathrm{Ln}\left(\mathrm{N}_{2} \mathrm{O}\right.\right.$ flux $\left./ \mathrm{NO}_{3}^{-}\right)$) against water filled pore space (WFPS) in conventional treatment in cropland A (CL-A), cropland B (CL-B), cropland C (CL-C), and grassland (GL) in Central Kalimantan, Indonesia. 